\title{
Structural and Metamorphic Evolution of the Karakoram and Pamir following India- Kohistan-Asia collision
}

M.P. SEARLE ${ }^{1 *}$, B.R. HACKER ${ }^{2}$

\author{
${ }^{1}$ Department of Earth Sciences, University of Oxford, Oxford OX1 3AN, UK. \\ *E-mail:mike.searle@earth.ox.ac.uk \\ ${ }^{2}$ Earth Science, University of California, Santa Barbara, CA93106, USA
}

Following the $\sim 50$ Ma India-Kohistan arc-Asia collision, crustal thickening uplifted the Himalaya (Indian plate) and the Karakoram, Pamir and Tibetan plateau (Asian plate). Whereas surface geology of Tibet shows limited Cenozoic metamorphism and deformation and only localised crustal melting, the Karakoram-Pamir show regional sillimanite- and kyanite-grade metamorphism, and crustal melting resulting in major granitic intrusions (Baltoro granites). U/Th- $\mathrm{Pb}$ dating shows that metamorphism along the Hunza Karakoram peaked at $\sim 83-62 \mathrm{Ma}$ and $44 \mathrm{Ma}$ with intrusion of the Hunza dykes at 52-50 Ma and 35 \pm 1.0 $\mathrm{Ma}$, and along the Baltoro Karakoram peaked at $\sim 28-22 \mathrm{Ma}$, but continued until 5.4-3.5 Ma (Dassu dome). Widespread crustal melting along the Baltoro batholith spanned 26.4-13 Ma. A series of thrust sheets and gneiss domes (metamorphic core complexes) record crustal thickening and regional metamorphism in the Central and South Pamir from 37-20 Ma. At 20 Ma, breakoff of the Indian slab caused large-scale exhumation of amphibolite-facies crust from depths of 30-55 km, and caused crustal thickening to jump to the fold-and-thrust belt at the northern edge of the Pamir. Crustal thickening, high-grade metamorphism, and melting are certainly continuing at depth today in the India-Asia collision zone.

200 words

\section{Introduction}

The India-Asia collision zone, actively shortening and thickening for at least 50 million years, provides the best and most recent example of a continent-continent collision zone to deduce processes of continental collison, including structural, metamorphic, and magmatic evolution. Major large-scale tectonic processes can be interpreted from a study of the exposed geology, and the deeper parts can be constrained from geophysics-particularly seismic studies. The Indian plate margin along the Himalaya is reasonably well constrained 
(see reviews by Yin and Harrison [2000], Hodges [2000] and Searle [2015]). Late Cretaceous-Paleogene ophiolite obduction was followed by Late Paleocene-Early Eocene subduction of the leading margin of India to UHP eclogite facies depths ( $>100 \mathrm{~km})$. Crustal thickening resulted in Late Eocene-Oligocene kyanite-grade metamorphism and OligoceneEarly Miocene decompression related sillimanite-grade metamorphism, partial melting and leucogranite formation.

Along the Asian margin (Hindu Kush-Karakoram-Pamir-Tibet; Figs. 1,2), the extent and ages of Cenozoic metamorphism related to the India-Asia collision are less well known (Figs. 3,4). The Karakoram ranges in North Pakistan expose a regional metamorphic terrane comprising andalusite-, kyanite-, and sillimanite-grade gneisses, migmatites and leucogranite dykes, and intrusions (Searle, 1991; Searle \& Tirrul, 1991; Rolland et al., 2001; Maheo et al., 2002). U-Pb geochronology shows that although there were important Late Cretaceous and Palaeogene thermal events, the major kyanite- and sillimanite-grade event in both the Hunza and Baltoro regions peaked at $\sim 28.2$ and $\sim 21.8 \mathrm{Ma}$ (Searle et al., 2010b; Palin et al., 2012). The youngest $\mathrm{U}-\mathrm{Pb}$ monazite ages are $5.4 \pm 0.1 \mathrm{Ma}$ and $3.5 \pm 0.1 \mathrm{Ma}$ in the Dassu dome, a contractional metamorphic core complex along the southern margin of the Karakoram. The Karakoram batholith is a $\sim 700 \mathrm{~km}$ long granitic batholith that includes pre-collision I-type granodiorites and granites metamorphosed to amphibolite facies (Hunza complex, K2 gneiss, Hushe gneisses; Searle et al., 1989, 1991; Crawford \& Searle, 1992), and post-collisional monzogranite-leucogranites with U-Pb ages from 40.2-13.9 Ma (Searle et al., 2010b). Most of the central batholith is composed of 21-13 Ma Baltoro granites with the younger Masherbrum sheet-like sill complex dated at 13.9 $\pm 0.2 \mathrm{Ma}$ (Searle et al., 2010b).

In the Pamir, U-Pb zircon geochronology records multiple magmatic events during the Cambro-Ordovician ( 575-410 Ma), Triassic (250-210 Ma), Jurassic (195-147 Ma), Cretaceous ( 120-80 Ma), Eocene (42-36 Ma), and Miocene (20-10 Ma) (Robinson et al., 2004, 2012; Schwab et al., 2004; Stearns et al., 2015; Aminov et al., 2017; Chapman et al., 2017, 2018b). The Pamir was probably a long-lasting magmatically thickened Andean-type orogen, similar to that recorded in the older components of the Karakoram batholith, the K2 gneiss and Muztagh Tower gneiss (Searle et al., 1989, 1990), and the Kohistan-LadakhGangdese batholith of south Tibet (Searle et al., 2011). Robinson (2015) and Chapman et al. (2018a,b) suggested that Pamir plateau was strongly affected by Mesozoic crustal shortening and thickening and was most likely topographically high since the Cretaceous.

$\mathrm{U} / \mathrm{Th}-\mathrm{Pb}$ data record two periods of high-grade metamorphism: one in the Triassic Jurassic (253-195 Ma; Yang et al., 2010; Schmidt et al., 2011; Robinson et al., 2012) and an 
Oligo-Miocene event across the central and southern Pamir (Robinson et al., 2004, 2007; Schmidt et al., 2011). U/Th- $\mathrm{Pb}$ monazite, U-Pb zircon, U-Pb titanite, U-Pb rutile, and Lu-Hf garnet dating indicate that the Cenozoic prograde metamorphism began at $37 \mathrm{Ma}$, culminated during peak burial at 22-19 Ma, and waned during exhumation through $\sim 6-8 \mathrm{~km}$ depth by $\sim 16 \mathrm{Ma}$ in the central Pamir and by $\sim 7 \mathrm{Ma}$ in the southern and northeastern Pamir (Robinson et al., 2007; Schmidt et al., 2011; Stearns et al., 2013; Stübner et al., 2013; Smit et al., 2014; Rutte et al., 2017a,b; Hacker et al., 2017).

Major tectonic questions about the India-Asia collision zone still to be solved include:

- what was the crustal structure of the Asian margin prior to the India-Asia collision and final closure of the intervening NeoTethyan ocean at $50 \mathrm{Ma}$ ?

- how did the Asian margin absorb the ca 1500-2000 km of crustal shortening since the collision?

- when did the Asian margin start to thicken, reach peak burial regional metamorphic PT conditions, and topographically rise following the collision?

- what is the composition and structure of the lower crust along the PamirKarakoram and Tibet regions?

- is the Karakoram-Pamir and Tibetan plateau region still thickening and shortening, as suggested by GPS data (Gan et al., 2007; Ischuk et al., 2013), or has orogenic collapse induced decreasing crustal thickness and lower topography?

- are the Karakoram-Pamir-Tibet regions in the early phase of cratonization?

In this paper we review geological and geochronological data for post- India-Asia collision metamorphism and magmatism across the Asian side of the orogenic belt in the Pamir and Karakoram. We synthesize these results and make comparisons east to the Tibetan plateau. We then propose a regional tectonic model for the structural and thermal evolution of the crust along the Asian margin, involving pre-collisional, Andean-type magmatism and metamorphism and post-collisional crustal shortening, thickening and regional metamorphism that continues to this day. We also propose that this vast region encompassing the Hindu Kush-Karakoram, Pamir and Tibetan Platea (Lhasa and Qiangtang terranes) is in the early stages of cratonization, forming a 'mobile belt' separating the Indian craton to the south from the stable Precambrian Tadjik-Tarim-North (and South) China cratons to the north. 


\section{India-Kohistan-Asia collision}

In the western Himalaya, a large-scale Cretaceous-Eocene intra-oceanic island arcthe Kohistan-Dras island arc-occurs between the Indian (Himalaya) and Asian (Hindu Kush, Karakoram, Pamir) plates (Jagoutz \& Schmidt, 2012; Boulilhol et al., 2013). The arc includes a complete sequence from upper mantle (Jijal complex peridotite) through lower crust garnet granulites and gabbro norites (Chilas complex), mid-crust amphibolites (Kamila complex) and upper crust arc lavas (Kohistan basalt-andesite-dacite-rhyolite volcanic sequence). The arc has been intruded by voluminous I-type subduction-related hornblendeand biotite granodiorites and granites of the Kohistan-Ladakh-Gangdese batholith. These granites span the Jurassic to Eocene and are related to the northward subduction of the NeoTethys oceanic slab beneath the Asian continent (Chung et al., 2005; Chu et al., 2006). Itype magmatism ended around $47 \mathrm{Ma}$ with the final closure of Neo-Tethys and the collision of India and Asia. Final marine sediments within the suture zone are precisely dated 51-50 Ma Nummulitic limestones that are overlain by thick continental molasse deposits derived from the north (Ladakh granites) as well as from the Indian plate to the south (Garzanti et al., 1987; Searle et al., 1997; Green et al., 2008; St-Onge et al., 2010).

A range of ages and tectonic scenarios has been proposed for the India-Asia collision. Palaeomagnetic data shows a dramatic slowing of the northward drift of India since $50 \mathrm{Ma}$, interpreted to be concomitant with continental collision (Molnar \& Stock, 2009). DeCelles et al. (2014) and $\mathrm{Hu}$ et al. (2015) proposed a 60-59 Ma India-Asia collision from the presence of Lhasa block-derived sediments deposited in the Tehyan Himalaya. Stratigraphic data from the Indus suture zone in Ladakh and south Tibet show that the final marine sediments deposited along the north Indian plate margin and within the suture zone are $50 \mathrm{Ma}$ (Garzanti et al., 1987; Searle et al., 1997; Zhu et al., 2005; Green et al., 2008). Van Hinsbergen et al. (2011) proposed a two-stage model for India-Asia collision where a so-called 'soft collision' of the Tethyan Himalaya with Asia at $\sim 50$ Ma was followed by a 'hard collision' of a contiguous Lesser Himalaya + India between 25-20 Ma. Their reconstruction shows an ocean ('Greater Indian basin') $1000 \mathrm{~km}$ wide during the period 50-25 Ma along the Main Central Thrust (MCT). There is no evidence anywhere along the Himalaya for a suture zone along the MCT and there is no evidence for slab break-off at this time (Searle, 2018, this volume).

$\mathrm{U}-\mathrm{Pb}$ geochronological data from igneous rocks record the end of subduction-related I-type magmatism along the Kohistan-Ladakh-Gangdese batholith around 50-47 Ma when the youngest, most-fractioned leucogranites were intruded as small volume dykes (St-Onge et al., 2010). The Kohistan arc has been obducted southward onto the Indian continental 
margin, probably during the Latest Cretaceous-Palaeocene, prior to final India-Asia collision. Bouilhol et al. (2013) proposed that the Shyok suture separating Kohistan from Asia closed at $\sim 40.4 \mathrm{Ma}$, based on U-Pb geochronology and Hf isotopes. By $50 \mathrm{Ma}$, and certainly by $40 \mathrm{Ma}$, there was no longer any ocean between India and Asia. There is no evidence of a later (25-20 Ma) collision along the Himalayan Main Central thrust, an intra-continental ductile shear zone along the base of the Cenozoic metamorphic rocks of the Greater Himalaya. The only probable 'slab break-off' event could be asigned to the 50-47 Ma period when the Tso Morari and Kaghan eclogites were exhumed along the northern leading edge of the Indian plate.

Following the $50 \mathrm{Ma}$ final closure of Neo-Tethys and India-Asia collision, crustal shortening and thickening occurred along both the Indian plate (Himalaya) and Asian plate (Karakoram-Pamir). Some $2000 \mathrm{~km}$ of convergence between India and Asia has been taken up since the collision (e.g. Johnson, 2002). GPS velocities obtained from measurements spanning 1998-2011 show that north-south convergence continues to this day in the western Himalaya and north across the Pamir (Gan et al., 2007; Ischuk et al., 2013).

\section{Indian plate Himalaya}

Crustal shortening and thickening during and following the India-Asia collision resulted in regional Barrovian-facies kyanite- and sillimanite \pm cordierite grade metamorphism and migmatisation along the Indian plate Greater Himalaya Sequence (GHS). $\mathrm{U} / \mathrm{Th}-\mathrm{Pb}$ ages of monazite, zircon and other accessory mineral phases show that prograde kyanite-grade metamorphism peaked $\sim 10 \mathrm{Myr}$ after the final closure of Tethys and IndiaAsia collision at $50 \mathrm{Ma}$ (Garzanti et al., 1997; Zhu et al., 2005; Green et al., 2008) spanning at least 41-11 Ma and possibly younger (e.g. Searle et al., 1999; Hodges, 2000; Godin et al., 2006; Jessup et al., 2008; Cottle et al., 2009, 2015; Searle, 2015). The GHS rocks are Proterozoic-Palaeozoic rocks of the Indian plate that were metamorphosed during the Cenozoic Himalayan orogeny and are bounded by the kinematically and temporally linked ductile shear zones along the Main Central Thrust (MCT) below, and the South Tibetan Detachment (STD) low-angle normal fault above (e.g. Grujic et al., 2002; Searle et al., 2008). In situ U/Th-Pb monazite dating records the earliest crustal melting in Nepal at $\sim 41-$ 36 Ma (Carosi et al., 2015). The bulk of ages relating to Himalayan leucogranite crystalization range between $\sim 21-18 \mathrm{Ma}$ (see review in Searle et al. 2010a). The youngest kyanite- and sillimanite + cordierite grade metamorphism is recorded in the Namche Barwa east Himalayan and Nanga Parbat west Himalayan syntaxes. The Namche Barwa syntaxis exposes kyanite and sillimanite-grade metamorphic rocks with monazite and titanite $\mathrm{U}-\mathrm{Pb}$ 
ages of 10-3 Ma (Zeitler et al., 2001). At Nanga Parbat, U-Pb monazite dating records 1.7 Ma migmatisation at $5 \mathrm{kbar}$, and 1.0 Ma garnet + cordierite melt veins formed at $3.5 \mathrm{kbar}$ (Crowley et al., 2009).

A series of metamorphic domes along the northern margin of the Indian plate, the North Himalayan domes, are a northward extension of the GHS metamorphic rocks bounded above by the folded STD shear zone. U/Th-Pb ages in the North Himalayan domes are synchronous with the GHS, spanning at least $\sim 40 \mathrm{Ma}$ to $16 \mathrm{Ma}$, with crustal melting forming leucogranites dated between 24-12 Ma (Lee et al., 2000, 2004; Lee \& Whitehouse, 2007; Stearns et al., 2013; Horton et al., 2014). Garnets from the Kangmar and Mabja gneiss domes in south Tibet gave Lu-Hf ages of 54-49 Ma (Smit et al., 2014) recording the earliest crustal thickening and garnet gowth along the northern part of the Indian plate. In the Leo Pargil dome, prograde metamorphism ended by ca $30 \mathrm{Ma}$, with low-pressure cordierite and sillimanite growth during decompression by $23 \mathrm{Ma}$, and leucogranite dyke injection between 23-18 Ma (Langille et al., 2012). Both protolith zircon ages (Quigley et al., 2008) and metamorphic monazite ages are closely synchronous with GHS metamorphic ages, confirming that the North Himalayan domes are a northward continuation of the GHS and formed during Himalayan contraction, not during crustal extension.

\section{Karakoram}

The Karakoram mountain ranges form the southern margin of Asia and are geologically equivalent to the Lhasa block north of the Ladakh-Gangdese batholith and to the Qiangtang block (Figs. 5,6). The southern margin is a high-grade metamorphic terrane with regional staurolite- kyanite- and sillimanite-grade gneisses, and partial melts in gneiss domes termed the Karakoram Metamorphic complex (Searle, 1991; Searle \& Tirrul, 1991; Searle et al., 1989, 2010b; Rolland et al., 2001). A major granite batholith, the Karakoram batholith includes both pre-collisional granodiorites and diorites subsequently metamophosed to amphibolites and orthogneisses, and post-collisional leucogranites related to Cenozoic crustal thickening and regional metamorphism. The northern Karakoram terrane is composed of Palaeozoic sedimentary rocks that are continuous into the southern Pamir.

Along the Karakoram Metamorphic complex, U-Pb zircon and monazite ages reveal peak metamorphic events both before and after the India-Asia collision (Fig. 7). In the Hunza valley, monazites from andalusite hornfels are 105.5 $\pm 0.8 \mathrm{Ma}$ (Palin et al., 2012) and monazites from sillimanite gneisses are 63.3 $\pm 0.4 \mathrm{Ma}, \sim 52-50 \mathrm{Ma}$ and 44.0 $\pm 2.0 \mathrm{Ma}$ (Fraser et al., 2001). Ages appear to decrease southward to highly graphitic garnet + staurolite schists 
that have a monazite age of $16.0 \pm 1.0 \mathrm{Ma}$. U-Pb ages from granitic rocks along the Hunza valley region record a wide range of ages from pre-collision (Hunza granodiorite, $105.7 \pm 0.5$ Ma; Fraser et al., 2001), Hushe and K2 gneiss (Searle et al., 1990), to post-collisional Hunza dykes, (Fig. 8; 52-50 and 35 Ma; Fraser et al., 2001) and the younger Sumayar granite (9.3 \pm $0.2 \mathrm{Ma}$; Fraser et al., 2001).

In the Baltoro valley region, monazites from a kyanite-grade gneiss are $28.0 \pm 0.5$ Ma, and high temperatures were maintained to at least $22 \pm 0.3 \mathrm{Ma}$ (Palin et al., 2012). Leucogranite dykes emmanating from the Baltoro granite batholith cut regional fabrics within the Karakoram Metamorphic complex to the south indicating that peak metamorphism and ductile fabrics preceded 22 Ma (Fig. 9) The deepest structural levels in the Dassu migmatite dome have Precambrian zircons $(1855 \pm 11 \mathrm{Ma})$ indicative of old protoliths, and younger metamorphic monazite ages of 5.4-3.5 Ma (Fraser et al., 2001; Searle et al., 2010b) indicative of young, deep crustal metamorphism. In the Baltoro region a large-scale granite batholith is dominantly composed of monzogranites to biotite + muscovite + garnet leucogranites (Figs 10,11 ) dated by $\mathrm{U}-\mathrm{Pb}$ at $19.8 \pm 0.5 \mathrm{Ma}$ through to $13 \mathrm{Ma}$ (Searle et al., 1992, 2010b).

High-grade metamorphism along the southern Karakoram lasted at least 37 m.y. (from $\sim 50-13 \mathrm{Ma}$ ) and possibly as long as $50 \mathrm{~m} . \mathrm{y}$. (from 63-13 Ma; Fig. 12). The major phase of crustal shortening and thickening occurred prior to intrusion of the Baltoro granite batholith, but metamorphism in the deeper parts of the crust continued to at least 5-3 Ma (Dassu gneiss dome). These ages show that the Karakoram experienced continuous Cenozoic crustal thickening and regional metamorphism throughout the India-Asia collision, a process that probably continues to this day, given the GPS data that shows active convergence across the entire Himalayan-Asia collision zone (Gan et al., 2007; Zubovich et al., 2016).

\section{Pamir}

The Pamir ranges form the western part of the Tibetan Plateau and are lateral equivalents of terranes of the Tibetan Plateau (Schwab et al., 2004; Robinson 2015; Chapman et al., 2017, 2018a,b) (Fig. 2). They are an arcuate series of mountain belts that show both south- and north-verging thrusts fanning out over the cratonic Tadjik and Tarim basins to the NW and NE respectively (Burtman \& Molnar, 1993; Schwab et al., 2004). It is classically divided into the North, Central and South Pamir belts, each bounded by major faults and shear zones (Fig. 3). The North Pamir is bounded along the north by the north-vergent Main Pamir thrust sytem, which was active from $\sim 25 \mathrm{Ma}$ and intensified at $\sim 15-10 \mathrm{Ma}$, when 
inversion of the Tadjik basin occurred (Coutand et al., 2002; Amidon \& Hynek 2010; Chapman et al., 2017, 2018a,b). Similar timing has been determined for inversion of the Tarim basin (Sobel \& Dumitru, 1997; Sobel et al., 2011). The Tadjik and Tarim basins are composed of Precambrian basement and Palaeozoic-Mesozoic magmatic arcs and accretionary systems of the Karakul-Mazar belt. Middle-lower crustal gneisses occur along a series of gneiss domes (metamorphic core complexes) in the North (Kurgovat dome in Tadjikistan; Kongur-Muztagh Ata domes in Xinjiang), Central (Yazgulom, Sarez, Muskol, Shatput domes) and South (Shakdara dome) Pamir (Fig. 3). These gneiss domes are bounded by normal sense shear zones interpreted as forming under extensional conditions during orogenic collapse (Stübner et al., 2013; Rutte et al., 2017a,b), as a consequence of Indian slab break-off (e.g. Stearns et al., 2015). Early studies suggested that most of the metamorphism was pre- India-Asia collision related to the collision of the Jinsha, Qiangtang, and Lhasa plates (Schwab et al., 2004). Recent studies however have shown that regional Cenozoic metamorphism overprinted earlier events (Robinson et al., 2004; Schmidt et al., 2011; Stübner et al., 2013a,b; Stearns et al., 2013, 2014; Smit et al., 2014a,b; Rutte et al., 2017a,b; Hacker et al., 2017). Figure 13 shows a compilation of proposed PTt paths from each of the Pamir domes or core complexes and Figure 14 shows the age data from each dome.

The Rushan-Pshart suture zone separates the North and Central Pamir from the South Pamir (Ruzhensev \& Shvolman, 1981; Robinson 2015). The South Pamir is geologically connected to the Hindu Kush terrane along the Pakistan-Afghanistan border (Hildebrand et al., 2000, 2001) and the northern Karakoram (Gaetani, 1991; Searle, 1991). The Hindu Kush and Karakoram terranes record an incomplete stratigraphic section with marine facies present up to Jurassic (Chitral slates) or possibly Cretaceous (Savoia limestone; Searle, 1991). There is no evidence for any marine sedimentation along the Karakoram ranges since.

The entire Pamir has been cut by large-scale strike-slip fault systems, notably the right-lateral Karakoram fault that extends from the Rushan-Psart suture zone in the North Pamir to the Indus suture zone in the SE (Searle et al., 1998; Phillips \& Searle, 2007; Robinson, 2009, 2015; Robinson et al., 2007). Maximum dextral offsets of geological markers show that a maximum of $\sim 120 \mathrm{~km}$, and a minimum of only $17-25 \mathrm{~km}$ occurred along the central part of the Karakoram fault (Searle et al., 2011), whereas along the north there is practically no strike-slip offset. Robinson et al. (2004) and Robinson (2009) suggested 150 $\mathrm{km}$ of dextral displacement along the northern Karakoram fault based on the separation of Jurassic carbonates. In the NW, the Karakoram fault merges into a series of high-angle 
normal faults along the Muji graben, and in the SE it terminates by merging into the IndusTsangpo suture zone in the Mount Kailas region of SW Tibet.

\section{North Pamir domes}

The North Pamir domes include the Kurgovat dome south of the Tadjik depression (Vlasov et al., 1991; Schmidt et al., 2011), and the Kongur and Muztagh Ata domes in Chinese Xinjiang (Robinson et al., 2004, 2007). Protoliths in the Kurgovat dome include Proterozoic to Carboniferous-Permian rocks (Vlasov et al., 1991) probably continuous eastwards along the northern Pamir to the Kongur massif. Regional Barrovian facies-series metamorphism in Kurgovat reached peak conditions of $600-650^{\circ} \mathrm{C}$ and $6.5-8.2 \mathrm{kbar}$ during the Mesozoic (Schmidt et al., 2011). Gneisses from the Muztagh Ata massif reached peak metamorphic conditions $\left(700-750^{\circ} \mathrm{C} ; 9-10 \mathrm{kbar}\right)$ with ages of monazite inclusions in garnet ranging from 30-11 Ma, interpreted as the timing of Oligocene-early Miocene prograde metamorphism with migmatisation at $\sim 14$ Ma (Robinson et al., 2007). In the Kongur Shan massif P-T conditions are a little lower than Muztagh Ata $\left(\sim 8 \mathrm{kbar}, 650^{\circ} \mathrm{C}\right)$ and have $\mathrm{Th}-\mathrm{Pb}$ monazite ages of 10-9 Ma (Robinson et al., 2007, 2012). Rutte et al. (2017a,b) documented a cluster of monazite ages at $\sim 25-20$ Ma interpreted as peak metamorphism, with a $\sim 14 \mathrm{Ma}$ popluation related to decompression melting (Fig. 10).

The Kongur and Muztagh Ata domes are also cored by metamorphic rocks exhumed along the footwall of large-scale extensional ductile shear zones that wrap around the domes. Along the western margin of Kongur Shan, the Miocene-Recent Kongur Shan extensional system shows top-to-west extensional fabrics whereas along the eastern margin the Gez shear zone shows dextral shear sense (Robinson et al., 2007, 2012). ${ }^{40} \mathrm{Ar} /{ }^{39} \mathrm{Ar}$ cooling ages suggest exhumation of footwall gneisses at 9-7.5 Ma (Robinson et al., 2007). The Muztagh Ata massif is bounded by the Early-Middle Miocene top-south Shenti shear zone to the south, and the top-east Kuke shear zone along the east (Robinson et al., 2007). We suggest that these data show multiple periods of 'extensional' fabrics related to exhumation of the core complexes in a compressional setting (e.g. Kongur Shan extensional fault system; similar to channel flow 'extensional' fabrics), dextral shearing along the Karakoram fault system and late (Pliocene-Pleistocene) minor east-west extension along the Muji graben. The data shows crustal thickening, metamorphism, widespread mid-crustal melting and ductile deformation during orogenic contraction occurred throughout the period 30-9 Ma and likely extending back to Paleogene. 


\section{Central Pamir domes}

The four main domes along the Central Pamir - the Yazgulom, Sarez, Muskol and Shatput domes - all show a similar thermal history. Prograde regional metamorphism in the kyanite and sillimanite stability fields $\left(650-700^{\circ} \mathrm{C} ; 0.8 \mathrm{GPa}\right)$ lasted from at least $35-30 \mathrm{Ma}$ through 22-21 Ma (Hacker et al., 2017). Structures within the domes and in the surrounding fold-and-thrust belts document tripling of the crustal section at this time (Rutte et al., 2013a). This was followed by exhumation and cooling through andalusite stability from $\sim 20$ Ma to 12 Ma documented by $\mathrm{U}-\mathrm{Pb},{ }^{40} \mathrm{Ar}-{ }^{39} \mathrm{Ar}, \mathrm{Rb}-\mathrm{Sr}$, and fission track dates (Hacker et al., 2017; Rutte et al., 2017b). The exhumation occurred largely along the North Muskol shear zone (NMSZ), a 1-3.5 km-thick, normal-sense, top-north ductile shear zone (Rutte et al., 2017a). The NMSZ is of regional extent and may connect north to the Kongur Shan and Muztagh Ata shear zones (Robinson et al., 2007, 2012). Extension along the Central Pamir domes is postulated to have been driven by slab breakoff, that also caused contraction to propagate from the Central Pamir into the Tajik basin (Stearns et al., 2013, 2015; Kufner et al., 2016; Hacker et al. 2017, Rutte et al., 2017b). This period corresponds to the regional metamorphic peak and timing of widespread crustal migmatization along the Muztagh Ata domes (Robinson et al., 2007), as well as the peak of crustal thickening and intrusion of the Baltoro crustal melt granites along the Karakoram (Searle et al., 2010b).

\section{South Pamir (Shakhdara) dome}

The South Pamir consists of a Cretaceous magmatic arc intruding a Paleozoic section (Stübner et al., 2013a, b; Chapman et al., 2017). Geochronology and structural studies show that much of the South Pamir was not significantly affected by Cenozoic deformation (Stübner et al., 2013a, b; Chapman et al., 2018a). Cenozoic metamorphism and deformation were concentrated in the giant Shakhdara dome, which exposes $\sim 2500 \mathrm{~km}^{2}$ of crystalline rocks-Precambrian paragneiss and orthogneiss, Cretaceous orthogneiss and plutonic rocks; it lies south of north-directed South Pamir thrust belt. The dome records a similar prograde metamorphic history as the central Pamir domes, except that the rocks were more deeply buried, apparently during shortening within the nearby thrust belt (Rutte et al., 2017; Chapman et al., 2018a). Orthogneisses in the dome include Proterozoic charnockites $(\sim 1.85$ $\mathrm{Ga}$ ), and were buried to PT conditions of $750-800^{\circ} \mathrm{C}$ and $1.5 \mathrm{GPa}$, equivalent to lower crust depths (Hacker et al., 2017). Prograde garnet growth between 37-27 Ma was followed by heating to $700-800^{\circ} \mathrm{C}$ at depths of $>50 \mathrm{~km}$ during peak metamorphism $\left(750-800^{\circ} \mathrm{C}, 1.5 \mathrm{GPa}\right.$, 21-19 Ma). Syn-metamorphic monazite $(22-21 \mathrm{Ma})$ and titanite growth ( 19 Ma) were 
accompanied by regional crustal melting (Schmidt et al., 2011; Stearns et al., 2015). The Shakhdara dome is overlain by a multi-km thick, top-SSE, normal-sense shear zone-the South Pamir Shear Zone - that roots southward (Stübner et al., 2013a). U/Th-Pb, Rb-Sr, ${ }^{40} \mathrm{Ar} /{ }^{39} \mathrm{Ar}$, fission track, and $(\mathrm{U}-\mathrm{Th}) / \mathrm{He}$ ages ${ }^{40} \mathrm{Ar} /{ }^{39} \mathrm{Ar}$ dates show that cooling and exhumation along this shear zone began at $18 \mathrm{Ma}$ and ended at $2 \mathrm{Ma}$ (Stübner et al., 2013b). This extension is focused along the dome margins - it is not widespread throughout the South Pamir - and occurred during orogen-scale contraction, and during shortening in the Tajik fold-and-thrust belt (Stübner et al., 2013a; Chapman et al., 2018a,b).

Eocene-Oligocene thickening in the South Pamir, with PT conditions peaking between $\sim 22-19 \mathrm{Ma}$, mimics the timing of prograde, peak metamorphic and melting history of the Hunza and Baltoro Karakoram regions (28-22 Ma; Fraser et al., 2001; Searle et al., 2010b; Palin et al., 2012) and the Greater Himalayan Sequence rocks along the Indian plate (Searle, 2015). This suggests the possible continuity of Cenozoic metamorphism from the Karakoram north into the Pamir.

\section{Dunkeldik alkaline intrusions}

In the southeastern Pamir, the Dunkeldik volcanic field shows several dykes and volcanic plugs consisting of a range of igneous rocks including ultra-potassic tephrite and phonolite, syenite and carbonatite that contain an important array of xenoliths. The host volcanic rocks have ${ }^{40} \mathrm{Ar} /{ }^{39} \mathrm{Ar}$ phlogopite and leucite/K-feldspar ages of $11.2 \mathrm{Ma}$ indicating the age of volcanic intrusion (Shaffer et al., 2017), similar to the ultrapotassic lamprophyre dykes intruding the southern Karakoram (Rex et al., 1988; Searle et al., 1992, 2010b). The xenoliths are eclogite- and granulite-facies crustal rocks. Thermobarometry and phase diagram modelling indicate that the granulite-facies xenoliths formed at PT conditions of 875- $1000^{\circ} \mathrm{C}$ and 1.8-2.3 GPa and the eclogite-facies xenoliths formed at $1000-110^{\circ} \mathrm{C}$ and $2.5-$ 2.8 GPa (Gordon et al., 2012; Hacker et al., 2005). These pressures show that the granulitefacies rocks originated from depths of $65-80 \mathrm{~km}$ and the eclogite-facies xenoliths were derived from $\sim 85-95 \mathrm{~km}$ depth. Some kyanite-bearing xenoliths are inferred to be metasedimentary, whilst clinopyroxene-bearing felsic rocks are probably meta-igneous. The abundance of Cretaceous zircons in igneous xenoliths implies that their source must have been the Asian plate (Ducea et al., 2003; Shaffer et al., 2017). Rare mantle xenoliths include phlogopite + garnet pyroxenites and websterites (Lutkov, 2003). Most xenoliths with high modal K-feldspar and phlogopite show evidence of metasomatism from an ultra-potassic and carbonatitic melt (Shaffer et al., 2017). 
Synchronous plutons intruding the country rocks are metaluminous monzogranites, syenogranites and syenites (Ke et al., 2008; Jiang et al., 2012). The granites have radiogenic

${ }^{87} \mathrm{Sr} /{ }^{86} \mathrm{Sr}$ ratios, are enriched in large ion lithophile elements and depleted in high field strength elements and sourced from depths of between 70-100 km (Jiang et al., 2012; Ke et al., 2008). Similar alkaline magmas including syenites and lamprophyres formed at lower crust depths in the southern Lhasa block of South Tibet (Chan et al., 2009). The high temperature of the primary magma $\left(\sim 880^{\circ} \mathrm{C}\right.$ for granites; $1100^{\circ} \mathrm{C}$ for syenites $)$ is compatible with the temperatures derived from the xenoliths both at Dunkeldik in the Pamir and in South Tibet.

\section{Hindu Kush-Pamir seismic zone}

The Hindu Kush-Pamir seismic zone is the deepest continental seismic zone known, with earthquake hypocenters recorded at depth between 60 and $300 \mathrm{~km}$ depths (Billington et al., 1977; Pegler \& Das, 1998; Sippl et al., 2013; Kufner et al., 2016, 2017). Tomographic models show a narrow zone of near vertical earthquakes descending deep into the mantle. Originally thought to represent a subducting small trapped oceanic slab (Billington et al., 1977; Pavlis \& Das, 2000), the earthquakes are now thought to represent a deep slab of subducting continental crust (Burtman \& Molnar, 1993; Searle et al., 2001). The geometry of the deep seismic zone has been interpreted either as a single highly contorted slab (Billington et al., 1977), or two subduction zones: a southern deeper Hindu Kush zone representing northward subduction of Indian plate lower crust, and a northern Pamir subduction zone representing southward subduction Tarim - Tadjik plate crust (Burtman \& Molnar, 1993; Searle et al., 2001; Negredo et al., 2007; Kufner et al., 2016, 2017 ).

Figure 15 shows a cross-section of the Pakistan Himalaya - Karakoram - Pamir profile with the major sutures, faults and orogenic terranes together with an interpretation of the Pamir and Hindu Kush seismic zones. The north-dipping Hindu Kush seismic zone shows a shallower zone (60-180 km depth) coinciding with a zone of low seismic P-wave velocity interpreted as subducting continental crust, and a deeper ( 180-260 km depth) part that is more seismically active and associated with high seismic velocities (Kufner et al., 2017). Kufner et al. (2017) interpreted the geometry of the Hindu Kush seismic zone to record lithosheric slab pull from beneath and sub-vertical extension in the entire slab. They further suggested that slab break-off is propagating from the west where the slab appears to be more intact than it is towards the east along the seismic zone. Searle et al. (2001) suggested that Hindu Kush seismic zone was a paradigm for the tectonic setting of formation of ultra-high 
pressure metamorphic rocks (diamond- and coesite-bearing eclogites). They proposed that the seismic gap at around 180-160 km depth could represent the depth at which the eclogitised root is detaching and sinking into the mantle. The subducting rocks are probably the old, cold Precambrian granulites that formed the basement to the upper crustal metamorphic rocks of the Himalaya. Searle et al. (2001) suggested that the Hindu Kush seismic zone initiated at about 7.5 Ma based on present-day convergence rates of $>40 \mathrm{~mm} /$ year.

\section{Tectonic synthesis}

The youngest marine sedimentary rocks in the Tadjik basin NW of the Pamir are upper Palaeocene Bukhara Group and middle Eocene Alai Group shallow marine limestones (Leith \& Alvarez, 1985). A shallow marine branch of the Tethys extended into the Tarim basin where the youngest marine sediments are midlle Eocene (earliest Priabonian; 37 Ma; Bosboom et al., 2011). Although the Pamir ranges are likely to have been topographically high with thick crust since the Late Cretaceous, inversion and uplift of the Tadjik and Tarim basins appears to have been initiated during the middle Eocene and reached a peak during the Miocene-Pliocene when thick molasse was deposited in the continental basin. Thrusting propagated northwards across the northern Pamir since the Miocene, and the youngest active Main Pamir Thrust along the northernmost Pamir was initiated 5-6 Ma (Thompson et al., 2015). The molasse rocks were subsequently folded into a spectacular fold-thrust belt extending around the northern Pamir (Burtman \& Molnar, 1993), the Peter the First range and the southern Tien Shan (Hamburger et al., 1992). In the Tarim Basin, NE of the Pamir, thick marine Mesozoic sediments are overlain by Neogene continental molasse deposits that are folded along both the NW (Tien Shan) and SW (Pamir) margins (Nishidai \& Berry, 1990). The sedimentary record of both the Tadjik and Tarim basins therefore suggests that significant uplift of the Pamir started around the middle Eocene, compatible with the peak metamorphic ages of 37-20 Ma in the Pamir gneiss domes (Schmidt et al., 2011; Stearns et al., 2013; Stübner et al., 2013a,b; Smit et al., 2014; Rutte et al., 2017a,b; Hacker et al., 2017).

The structure and metamorphism of the Pamir and Karakoram have many aspects in common with the Greater Himalayan sequence of the Indian plate (Fig. 16). 20-30 million years of crustal convergence formed fold nappes that thickened the crust, resulting in regional prograde kyanite- and sillimanite-grade metamorphism. Rocks buried to mid- or lower crust depths were metamorphosed and then exhumed during convergence by return flow. We propose that extensional fabrics along the top of the Pamir domes are related to extrusion and 
exhumation of deeper footwall gneisses beneath a passive 'roof fault' or low-angle extensional detachment, in a contractional tectonic setting. All the fabrics along the Karakoram metamorphic sequence are related to contraction and exhumation by thrusting along the base and normal sense detachments along the top. The Baltoro granites are interpreted to have intruded along this detachment to explain the PT jump from kyanite and sillimanite grade rocks to the south to low-grade or unmetamorphosed Paleozoic sedimentary rocks to the north (Searle \& Tirrul 1991)

The Karakoram-Pamir and Tibetan plateau both have similar thickness crust (ca 70-80 km; Tilmann et al., 2003; Nabelek et al., 2009; Mechie et al., 2011, 2012) and have absorbed somewhere between $\sim 1500-2000 \mathrm{~km}$ of north-south shortening (Johnson, 2002). The two regions show very different geology at the surface: the Karakoram and Pamir showing mainly deep crustal metamorphic and magmatic rocks, whereas Tibet shows mainly upper crustal sedimentary rocks with a major Andean-type granite batholith along the southern margin of Asian plate in the Ladakh-Gangdese range. The timing of peak kyanite- and sillimanite-grade metamorphism along the Pamir (Fig. 12) is synchronous with the timing of regional metamorphism along the southern Karakoram (Searle et al., 2010b; Palin et al., 2012) and also with $\mathrm{U}-\mathrm{Pb}$ ages from kyanite and sillimanite grade gneisses and migmatites from the southeast region of the Lhasa Block near Namche Barwa (Palin et al. 2014).

\section{Cratonization of the Karakoram-Pamir-Tibet crust?}

Cratonization is the process whereby large tracts of continental crust, often recycled multiple times during orogenic events, cool, consolidate and stabilize into large-scale stable continental cratons or 'shields' (e.g. Windley, 1977). Three main cratons make up much of eastern Asia: the Siberian craton, the North + South China (Yangtse) cratons and the Indian Shield. The Siberian craton amalgamated mainly during the Archean-Early Proterozoic, although major magmatic events continued into the Palaeozoic and Permo-Triassic Siberian Trap volcanism (Cherepanova et al., 2013) with a considerable thickness of overlying Phanerozoic sedimentary cover rocks. The North and South China cratons consist of large stable continental cratons composed of Archean gneisses, some of which were reworked into Proterozoic metamorphic rocks and intruded by mafic dyke swarms and anorogenic magmatic zones (e.g. Zhai, 2011). The North China craton probably extends westward to the Tarim (and Tadjik) stable continental block north of the Pamirs. The Indian Shield is composed of a series of stable Mid- to Late Archean cratons surrounded by shear zones and 
fold belts (Sharma, 2009). The Central Asian orogenic belt, also called the 'Altaids', from the Urals east across Mongolia to the Pacific coast, south of the Siberian craton, separate the Siberian craton to the north from the North China craton to the south. This belt formed from large-scale Paleozoic subduction-accretion complexes amalgamated during the Paleozoic (Sengör et al., 1993).

Surface wave tomography reveals that Tibet is underlain by thick lithosphere, similar to that beneath cratons (McKenzie \& Preistley, 2016). Simple models of catastrophic lithospheric delamination beneath the Tibetan plateau $7-8$ Ma ago (e.g. Houseman et al., 1981) are most likely incorrect because it is known that Tibetan crust (as in the Pamir and Karakoram) has been thick and topographically high for at least the last 50 million years, and eruption and emplacement of ultra-potassic shoshonitic volcanics and lower crust-derived adakites spanned the last 50 Ma (Chung et al., 2003, 2005; Searle 2015). The double thickness of crust in Tibet resulted from the underthrusting of lower Indian crust (old, cold, Indian shield granulite), rocks that prior to collision underlay the Neoproterozoic and Phanerozoic rocks that make up the Himalaya (Argand 1924; Searle 2015). Deep crustal xenoliths from the Pamir, Qiangtang and Lhasa blocks reveal that temperatures at the base of the crust and in the upper mantle were extremely high $\left(>900-1000^{\circ} \mathrm{C}\right)$ during the Late Miocene-Pliocene. Today however, the mantle beneath southern Tibet is relatively cold (Preistley et al., 2008), whereas the mantle beneath the Kunlun - northern Tibet and the Pamir is relatively hot, the source for Pliocene-Recent shoshonitic volcanics, the Karakoram and Pamir alkaline complexes and lower uppermost mantle wavespeeds. In the west, the Karakoram is also underlain by underthrust lower Indian crust from the south, almost certainly converted to HP-HT granulite or eclogite facies. The Pamir is underlain by underthrust Tadjik-Tarim lower crust from the north (Schneider et al., 2013).

The geological evolution of the Karakoram and Pamir shows a historic record that stretches from the Precambrian to the Neogene with multiple episodes of crustal shortening, thickening and metamorphism with both subduction-related Andean-type magmatism, and extensive post-collisional crustal melt S-type granites. The Pamir shares a similar structural and metamorphic history with the Karakoram, both of which have excessively thick crust, Miocene regional high-grade metamorphism and melting, and extremely high post-Middle Miocene exhumation and erosion rates. Similar rocks probably underlie the deepest parts of the Qiangtang terrane of central Tibet, but due to extremely low erosion and exhumation rates, remain buried at depth. Full cratonization of the Karakoram-Pamir-Tibet terrane will only occur once India-Asia convergence ends and the mountain ranges cool and consolidate. 
With the end of orogenesis some time in the future, erosion will reduce the crustal thickness and remove the upper part of the crust. Eventually the entire eastern Asia could become one giant supercontinent composed of stable, old cratons (Siberian, North China + Yangtse and India) surrounded by and separated by eroded younger 'mobile belts' (Central Asian orogenic belt and Karakoram-Pamir mobile belts). Whether the Tibetan plateau becomes cratonised or becomes part of the mobile belt largely depends on the thermal structure of the deep crust, and the extent of Cenozoic metamorphism overprinting older Precambrian basement rocks.

The geological evolution of the Karakoram and Pamir suggests that long-lived geological processes involving accretion of island arc terranes, pre-collision subduction-related magmatism, continental collision, post-collision crustal shortening and thickening, crustal melting and erosion and recycling of crustal material may indicate that these terranes are in the process of becoming a craton. The components of the Karakoram-Pamir future 'mobile belt' include:-

- underthrust lower crustal Archean-Proterozoic crust (granulites, amphibolites) of India, partly re-metamorphosed to Neogene ultra-high pressure granulite or eclogite.

- Palaeozoic-lower Mesozoic supra-crustal sedimentary rocks.

- pre-collision subduction-related I-type granodiorites-granites of the Asian margin, some of which were re-metamorphosed to amphibolite facies in the Cenozoic.

- post-collision regional Barrovian facies series kyanite- and sillimanite-grade metamorphic rocks spanning at least 60 m.y.

- post-collision S-type crustal melt granites (Baltoro granites) spanning at least 20 m.y.

- late orogenic mantle-derived alkaline intrusions (lamprophyres, syenites, shoshonites).

We speculate that the deepest parts of the Karakoram and Pamir crust today between ca 50-80 $\mathrm{km}$ depth are composed of young high-pressure granulite- or eclogite-facies material. The lowermost crust of southern Tibet is likely to be in similar present day P-T conditions, albeit not exposed. Xenoliths in young volcanic rocks show extreme high pressures and temperatures of lowermost crust (Hacker et al., 2000). Since India and Asia continue to converge to this day (Gan et al., 2007; Ischuk et al., 2013), it is likely that that HP and HT metamorphism is occuring throughout the lower crust of the Karakoram, Pamir and Tibetan plateau. The NNE-SSW India-Asia convergence has been ongoing since at least $50 \mathrm{Ma}$, and there is no evidence in the geological record for any 'orogenic collapse', decreasing of crustal thickness or lowering of topographic height. 


\section{Conclusions}

High-grade regional metamorphism and migmatisation occurred across large swaths of the Pamir and Karakoram following the India-Asia collision at 55-50 Ma, unlike the presently exposed levels of the Tibetan plateau. All these regions have crustal thickness in excess of $70 \mathrm{~km}$ (Wittlinger et al., 2004; Schulte-Pelkum et al., 2005; Rai et al., 2006; Mechie et al., 2012). High exhumation and erosion rates have exposed these lower and midcrustal rocks at the surface in the Karakoram and Pamir, whereas in Tibet very slow erosion rates have not been sufficient to exhume these rocks. Only in a few rare locations in south (Nyenchen Tanggla; Weller et al., 2015), north (Ulugh Muztagh; Molnar et al., 1987), and east (Gongga Shan; Searle et al., 2016) Tibet have young Cenozoic metamorphic or granitic rocks been exposed. Small volume lower crust-derived adakite melts were intruded across the Tibetan plateau following the India-Asia collision. These adakites are intermediate to felsic in composition, and require a garnet-bearing amphibolite or eclogite source (Chung et al., 2003).

In Tibet, large-scale underthrusting of Indian granulite lower crust has resulted in passive uplift of older rocks across the southern (Lhasa block) and central (Qiangtang block) plateau (Argand, 1924; Searle et al., 2011; Searle, 2015). In the Western HimalayaKarakoram-Pamir profile, Indian lower crust may have underthrust north as far as the southern Pamir in the Shaksgam region and Tarim crust underthrust southwards beneath the North and Central Pamir (Burtman \& Molnar, 1993). The deep Hindu Kush seismic zone with earthquake hypocenters from $60-300 \mathrm{~km}$ depth represents a narrow zone subducted lower Indian continental crust. Extremely high P-T $\left(1000^{\circ} \mathrm{C} ; 2.8-2.5 \mathrm{GPa}\right)$ eclogite and granulite xenoliths in Miocene potassic dykes from the Dunkeldik swarm in the southern Pamir (Ducea et al., 2003; Hacker et al., 2005; Gordon et al., 2012; Shaffer et al., 2017) show that alkaline magma formed at $\sim 80-90 \mathrm{~km}$ depth during the later stages of orogenesis. Similar deep crustal xenoliths have been recovered from southwest Tibet (Chan et al., 2009). These akaline igneous complexes are an important orogenic component and not intra-plate or anorogenic like many A-type granites.

We suggest that the lower crust in both the Karakoram and Pamir is likely old, unradiogenic felsic and mafic granulite, whereas the middle crust is composed of radiogenic gneisses derived from Cenozoic metamorphism and crustal melting. The presence of Oligocene-Miocene lamprophyric dykes across the Karakoram (Rex et al., 1988; Searle et al., 2010) and ultrapotassic mantle-derived intrusions across the Pamir (Ducea et al., 2003; Hacker et al., 2005; Shaffer et al., 2017) suggest that the mantle may have contributed an 
extra heat source, besides internal radiogenic heating and crustal thickening, for widespread Cenozoic metamorphism and melting.

The Pamir domes all show classic features of continental metamorphic core complexes, but formed during plate convergence, not divergence (Stübner et al., 2013a; Rutte et al., 2017a). Continuous post-collisional India-Asia convergence, crustal thickening, regional metamorphism, and partial melting combined to produce a thick, thermally weakened crust by the Miocene. Breakoff of the Indian slab at $\sim 20 \mathrm{Ma}$ then triggered basal heating and a rebalancing of regional forces that allowed contraction to jump northward to the North Pamir, and extension to commence in the South and Central Pamir (Stearns et al., 2013; Stübner et al., 2013a; Kufner et al., 2016; Rutte et al., 2017a; Shaffer et al., 2017). We also speculate that the Karakoram, Pamir and Tibetan plateau may show an early phase of formation of intra-cratonic mobile belt forming a large area between the Indian shield to the south and the Tadjik-Tarim-Yangtse craton to the north.

Finally, the distribution and depths of intermediate and deep earthquakes along the Hindu Kush-Pamir seismic zone suggest that the southwards subducting Tadjik-Tarim crust extends beneath the north and central Pamir, whereas the northward subducting Indian crust extends as far as the Hindu Kush seismic zone and its westward extension along the southern Pamir, and northern Karakoram (Searle et al., 2001; Negredo et al., 2007; Kufner et al., 2016). The thick crust and high topography is maintained by this crustal-scale pop-up structure and continuing north-south compression. We suggest that ultrahigh-pressure metamorphism is likely occurring today along the deep Hindu Kush seismic zone, and that high-pressure granulite and lower crust eclogite facies metamorphism is actively forming today at deep levels of the Karakoram and Pamir.

\section{Acknowledgements}

M.P. Searle's work in the Karakoram was supported by NERC (UK) grants and Oxford University, and B.R. Hacker's work in the Pamir was supported by supported by University of California, Santa Barbara, and NSF grants EAR-1551054, EAR-1419751, and EAR1008760. We thank Alex Robinson and Randall Parrish for extremely detailed and insightful reviews of the paper. Fig. 2. DEM was produced using the Generic Mapping Tools by Wessel and Smith, courtesy of Austin Elliott. 


\section{References}

AMIDON, W.H. \& HYNEK, S.A. 2010. Exhumation history of the north central Pamir. Tectonics, 29, TC5017 doi:10.1029/2009TC002589

AMINOV, J., DING, L., and 7 others. 2017. Pamir Plateau formation and crustal thickening before the India-Asia collision inferred from dating and petrology of the 110-92 Ma Southern Pamir Volcanic sequence. Gondwana Research, 51, 310-326. http://dx.doi.org/10.1016/j.gr.2017.08.003

ARGAND, E. 1924. Le tectonique de 1'Asie, In: Proc. 13 ${ }^{\text {th }}$ Int. Geol. Congress, Brussels, 7, 171-372.

BILLINGTON, S., ISACKS, L.B. \& BARAZANGI, M. 1977. Spatial distribution of mantle earthquakes in the Hindu Kush-Pamir region: a contorted Benioff zone. Geology, 5, 699-704.

BOUILHOL, P., JAGOUTZ, O., HANCHAR, J.M. \& DUDAS, F.O. 2013. Dating the IndiaEurasia collision through magmatic records. Earth and Planetary Science Letters, 366, 163175.

BOSBOOM, R.E., DUPONT-NIVET, G. and 9 others. 2011. Late Eocene sea treat from the Tarim Basin (west China) and concomitant Asian paleoenvironmental change. Palaeogeography, Palaeoclimatology, Palaeoecology, 299, 385-398.

BURTMAN, V.S. \& MOLNAR, P. 1993. Geological and Geophysical evidence for deep subduction of continental crust beneath the Pamir. Geological Society America, Special Paper 281.

CAO, K., WANG, G-C, VAN DER BEEK, P., BERNET, M., \& ZHANG, K-X. 2013. Cenozoic thermo-tectonic evolution of the northeastern Pamir revealed by zircon and apatite fission track thermochronology. Tectonophysics, 589, 17-32.

CAROSI, R., and 9 others, 2015. Eocene partial melting recorded in peritectic garnets from kyanite-gneiss, Greater Himalayan Sequence, central Nepal. In: Mukherjee, S. et al. (Eds) Tectonics of the Himalaya. Geological Society, London, Special Publication, 412, 111-129.

CHAN, G.H-N., WATERS, D.J., SEARLE, M.P., AITCHISON, J.C., HORSTWOOD, M.S.A., CROWLEY, Q., LO, C-H. \& CHAN, J.S-L. 2009. Probing the basement of southern Tibet: evidence from crustal xenoliths entrained in a Miocene ultrapotassic dyke. Journal of the Geological Society London, 166, 45-52.

CHAPMAN, J. B., CARRAPA, B., BALLATO, P., DECELlES, P. G., WORTHINGTON, J., OIMAHMADOV, I., GADOEV, M. \& KETCHAM, R. 2017. Intracontinental subduction beneath the Pamir Mountains: Constraints from thermokinematic modeling of shortening in the Tajik fold-and-thrust belt. GSA Bulletin, 129, 1450-1471.

CHAPMAN, J. B., ROBINSON, A. C., CARRAPA, B., VILLARREAL, D., WORTHINGTON, J., DECELLES, P. G., KAPP, P., GADOEV, M., OIMAHMADOV, I. \& GEHRELS, G. 2018a. Cretaceous shortening and exhumation history of the South Pamir terrane. Lithosphere. https://doi.org/10.1130/L691.1

CHAPMAN, J. B., SCOGGIN, S. H., KAPP, P., CARRAPA, B., DUCEA, M. N., WORTHINGTON, J., OIMAHMADOV, I. \& GADOEV, M. 2018b. Mesozoic to Cenozoic magmatic history of the Pamir. Earth and Planetary Science Letters, 482, 181-192. 
CHATELAIN, J.L., ROEKER, S.W., HATZFIELD, D. \& MOLNAR, P. 1980. Microearthquake seismicity and fault plane solutions in the Hindi Kush region and their tectonic implications. Journal Geophysical Research, 85, 1365-1387.

CHEREPANOVA, Y., ARTEMIEVA, I.M., THYBO, H. \& CHEMIA, Z. 2013. Crustal structure of the Siberian craton and West Siberian basin: An appraisal of existing seismic data. Tectonophysics, 609, 154-183.

CHU, M-F., CHUNG, S-L., SONG, B. et al. 2006. Zircon U-Pb and Hf isotope constraints on the Mesozoic tectonics and crustal evolution of southern Tibet. Geology, 34 (9), 745-748.

CHUNG, S-L., LIU, D. et al. 2003. Adakites from continental collision zones: Melting of thickened lower crust beneath southern Tibet. Geology, 31, 1021-1024.

CHUNG, S-L., CHU, M-F., ZHANG, Y. et al. 2005. Tibetan tectonic evolution inferred from spatial and temporal variations in post-collisional magmatism. Earth Science Reviews, 68, 173-196.

CORFIELD, R.I. \& SEARLE, M.P. 2000. Crustal shortening estimates across the north Indian continental margin, Ladakh, NW Himalaya. In: Khan, M.A. et al. (Eds) Tectonics of the Nanga Parbat syntaxis and the western Himalaya. Geological Society, London, Special Publication, 170, 395-410.

COTTLE, J.M, SEARLE, M.P., HORSTWOD, M.S.A., \& WATERS, D.J. 2009. Timing of mid-crustal metamorphism, melting and deformation in the Mount Everest region of southern Tibet revealed by U(-Th)-Pb geochronology. Journal of Geology, 117, 643-664.

COTTLE, J.M., SEARLE, M.P., JESSUP, M.J., CROWLEY, J.L. \& LAW, R.D. 2015. Rongbuk re-visited: geochronology of leucogranites in the footwall of the South Tibetan Detachmnet System, Everest region, Southern Tibet. Lithos, 227, 94-106. http://dx.doi.org/10.1016/j.lithos.2015.03.019

COUTAND, I., STRECKER, M.R., ARROWSMITH, J.R., HILlEY, G., THIEDE, G., KORJENKOV, A. \& OMURALIEV, M. 2002. Late Cenozoic tectonic development of the intramontane Alai valley (Pamir - Tien Shan region, central Asia): an example of intracontinetal deformation due to the Ind0-Eurasia collision. Tectonics, 21, 1053 doi:10.1029/2002TC001358

CRAWFORD, M.B. \& SEARLE, M.P. 1992. Field relationships and geochemistry of precollisional (India-Asia) granitoid magmatism in the central Karakoram. Tectonophysics, 206, 171-192.

CRAWFORD, M.B. \& SEARLE, M.P. 1993. Collision-related granitoid magmatism and crustal structure of the Hunza Karakroam, north Pakistan. In: Treloar, P.J. \& Searle, M.P. (Eds) Himalayan Tectonics. Geological Society, London Special Publication, 74, 53-68.

CROWLEY, J.L., WATERS, D.J., SEARLE, M.P. \& BOWRING, S.A. 2009. Pleistocene melting and rapid exhumation of the Nanga Parbat massif, Pakistan: Age and P-T conditions of accessory mineral growth in migmatite and leucogranite. Earth and Planetary Science Letters, 288, 408-420.

DEBON, F., LEFORT, P., DAUTEL, D., SONET, J. \& ZIMMERMANN, J.L. 1987. Granites of western Karakoram and northern Kohistan (Pakistan): a composite MidCretaceous to Upper Cenozoic magmatism. Lithos, 20, 19-40. 
DUCEA, M.N., LUTKOV, MINAEV, V.T. et al. 2003. Building the Pamirs: the view from the underside. Geology, 31, 849-852.

DECELlES, P.G., ROBINSON, D.M., QUADE, J., OJHA, T., GARZIONI, C. \& COPELAND, P. 2001. Stratigraphy, structure and tectonic evolution of the Himalayan foldthrust belt in western Nepal. Tectonics, 20, 487-509.

DE CELlES, P.G., KAPP, P., GEHRELS, G. \& DING, L. 2014. Paleocene - Eocene foreland basin evolution in the Himalaya of southern Tibet and Nepal: Implications for the age of initial India-Asia collision. Tectonics, 33, 824-849.

ENGLAND, P. \& HOUSEMAN, G. 1989. Extension during continental convergence, with application to the Tibetan Plateau. Journal of Geophysical Research, 94, 17561-17579.

FRASER, J.E., SEARLE, M.P., PARRISH, R.R. \& NOBLE, S.R., 2001, Chronology of deformation, metamorphism, and magmatism in the southern Karakoram Mountains. Geological Society of America Bulletin, 113, 1443-1455.

GAETANI, M. 1997. The Karakoram Block in Central Asia from Ordovician to Cretaceous. Sedimentary Geology, 109 (3-4), 339-359.

GAN, W., ZHANG, P., SHEN, Z-H., et al. 2007. Present-day crustal motion within the Tibetan Plateau inferred from GPS measurements. Journal of Geophysical Research, 112, B08416. http://dx.doi.org/10.1029/2005JB004120

GARZANTI, E., BAUD, A. \& MASCLE, G. 1987. Sedimentary record of the northward flight of India and its collision with Eurasia (Ladakh Himalaya, India). Geodynamica Acta, 1, 297-312.

GODIN, L., GRUJIC, D., LAW, R.D \& SEARLE, M.P. 2006. Channel flow, ductile extrusion and exhumation in continental collision zones: An Introduction: In: Law, R.D., Searle, M.P. \& Godin, L. (Eds). Channel flow, ductile extrusion and exhumation in continental collision zones, Geological Society of London, Special Publication, 268, 1-23.

GORDON, S.M., LUFFI, P., HACKER, B.R. et al. 2012. The thermal structure of continental crust in active orogens: Insight from Miocene eclogite and granulite facies of the Pamir. Journal of Metamorphic Geology, 20, 413-434.

GREEN, O.R., SEARLE, M.P., CORFIELD, R.I. \& CORFIELD, R.M. 2008. CretaceousTertiary carbonate platform evolution and the age of the India-Asia collision along the Ladakh Himalaya (Northwest India). Journal of Geology, 116, 331-353.

GRUJIC, D., HOLLISTER, L. \& PARRISH, R.R. 2002. Himalayan metamorphic sequence as an orogenic channel: insight from Bhutan. Earth and Planetary Science Letters, 198, 177191.

HACKER, B., GNOS, E., RATSCHBACHER, L. et al. 2000. Hot and dry deep crustal xenoliths from Tibet. Science, 287, 2463-2466.

HACKER, B., LUFFI, R., LUTKOV, V. et al. 2005. Near ultrahigh pressure processing of continental crust: Miocene crustal xenoliths from the Pamir. Journal of Petrology, 46, 16611687.

HACKER, B.R., L. RATSCHBACHER, D. RUTTE, M. A. STEARNS, N. MALZ, K. STÜBNER, A. R. C. KYLANDER-CLARK, J. PFÄNDER, \& A. EVERSON. 2017. Building the Pamir-Tibet Plateau-Crustal stacking, extensional collapse, and lateral extrusion 
in the Central Pamir: 3. Thermobarometry and Petrochronology of Deep Asian Crust, Tectonics, 36, doi:101002/2017TC004488

HAMBURGER, M.W., SAREWITZ, D.R., PAVLIS, T.L. \& POPANDOPULO, G.A. 1992. Structural and seismic evidence for intracontinental subduction in the Peter the First Range, Central Asia. Geological Society of America, Bulletin, 104, 397-408.

HILDEBRAND, P.R., NOBLE, S.R., SEARLE, M.P., PARRISH, R.R. \& SHAKIRAULLAH 1998. Tectonic significance of $24 \mathrm{Ma}$ crustal melting in the eastern Hindu Kush, Pakistan. Geology, 26, 871-874.

HILDEBRAND, P.R., SEARLE, M.P., SHAKIRUALLAH, KHAN, Z. \& VAN HEST, H.J. 2000. Geological evolution of the Hindu Kush, NW Frontier Pakistan: active margin to continent-continent collision. In: Khan, M.A. et al. (Eds) Tectonics of the Nanga Parbat syntaxis and Western Himalaya. Geological Society, London Special Publication, 170, $277-$ 293.

HILDEBRAND, P.R., NOBLE, S.R., SEARLE, M.P., WATERS, D.J. \& PARRISH, R.R. 2001. Old origin for an active mountain range: Geology and geochronology of the eastern Hindu Kush, Pakistan: Geological Society of America Bulletin, 113, 625-639.

HODGES, K.V. 2000. Tectonics of the Himalaya and southern Tibet from two perspectives. Geological Society of America Bulletin, 112, 428-432.

HORTON, F., LEE, J., HACKER, B.R., BOWMAN-KAMAHA'O, M. \& COSCA, M. 2014. Himalayan gneiss dome formation in the middle crust and exhumation by normal faulting: New geochronology of Gianbul dome, northwestern India, Geological Society of America Bulletin, doi:10.1130/B31005.1.

HOUSEMAN, G. \& ENGLAND, P.C. 1996. A lithosphere thickenening model for the IndoAsian collision. In: Yin, A. \& Harrison, T.M. (Eds) The Tectonic Evolution of Asia, Cambridge University Press, 3-17.

HOUSEMAN, G., McKENZIE, D. \& MOLNAR, P. 1981. Convective instability of a thickened boundary layer and its relevance for thermal evolution of continental convergent belts. Journal of Geophysical Research, 86, 6115-6132.

HU, X., GARZANTI, E., MOORE, T. \& RAFFI, I. 2015. Direct dating of India-Asia collision onset at the Selandian (middle Paleocene, $59 \pm 1 \mathrm{Ma}$ ). Geology, 43, 859-862.

ISCHUK, A. et al., 2013. Kinematics of the Pamir and Hindu Kush regions from GPS geodesy. Journal of Geophysical Research, Solid Earth, 118, 2408-2416 doi: 10.1002/jgrb.50185

JACKSON, J., McKENZIE, D., PRIESTLEY, K. \& EMMERSON, B. 2008. New views on the structure and rheology of the lithosphere. Journal of the Geological Society, London, 165, 453-465.

JAGOUTZ, O. \& SCHMIDT, M.W. 2012. The formation and bulk composition of modern juvenile continental crust: The Kohistan Arc. Chemical Geology, 298(9), 76-96.

JIANG, Y-H., LIU, Z., JIA, R-Y., LIAO, S-Y., ZHOU, Q. \& ZHAO, P. 2012. Miocene potassic granite-syenite association in western Tibetan Plateau.: implication for shoshonitic and high Ba-Sr granite genesis. Lithos, 134, 146-162. 
JESSUP, M.J., COTTLE, J.M, SEARLE, M.P. et al. 2008. P-T-t-D paths of Everest Series schists, Nepal. Journal of Metamorphic Geology, 26, 717-739.

JOHNSON, M.R.W. 2002. Shortening budgets and the role of continental subduction during the India-Asia collision. Earth Science Reviews, 59, 101-123.

KE, S., LUO, Z., MO, X., ZHANG, W., LIANG, T., \& ZHAN, H. 2008. The geochronology of the Taxkorgan alkali complex, Pamir. Acta Petrologica Sinica, 24, 315-324.

KUFNER, S-K., et al. 2016. Deep India meets deep Asia: Lithospheric indentation, delamination and break-off under the Pamir and Hindu Kush (Central Asia). Earth and Planetary Science Letters, 435. 171-184.

KUFNER, S-K., et al. 2017. Zooming into the Hindu Kush slab break-off: A rare glimpse on the terminal stage of subduction. Earth and Planetary Science Letters, 461. 127-140.

LANGILLE, J.M., JESSUP, M.J., COTTLE, J.M., LEDERER, G. \& AHMAD, T. 2012. Timing of metamorphism, melting and exhumation of the Leo Pargil dome, northwest India. Journal of Metamorphic Geology, doi:10.1111/j.1525-1314.2012.00998.x

LEE, J. \& WHITEHOUSE, M.J. 2007. Onset of mid-crustal extensional flow in soutehrn Tibet: Evidence from U/Pb zircon ages. Geology, 35, 45-48.

LEE, J., HACKER, B.R., DINKLAGE, W.S., GANS, P.B., CALVERT, A., WANG, Y., \& CHEN, W., 2000. Evolution of the Kangmar dome, southern Tibet: structural, petrological, and thermochronologic constraints. Tectonics, 19, 872-895, doi:10.1130/G22842A.1

LEE, J., HACKER, B.R. \& WANG, Y. 2004. Evolution of the north Himalayan gneiss domes: Structural and metamrohic studies in Mabja dome, southern Tibet. Journal of Structural Geology, 26, 872-895. Doi: 10.1016/j.jsg.2004.02.013

LEITH, W. \& ALVAREZ, W. 1985. Structure of the Vakhsh fold-and-thrust belt, Tadjik SSR: Geologic mapping on a Landsat image base. Geological Society of America, Bulletin, 96, 875-885.

LUTKOV, V.S. 2003. Petrochemical evolution and genesis of potassium pryroxeniteeclogite-granulite association in the mantle and crustal xenoliths from Neogene fergusites of South Pamir, Tadjikistan. Geochimia, 3, 254-265.

McKENZIE, D. \& PRIESTLEY, K. 2016. Speculation on the formation of cratons and cratonic basins. Earth and Planetary Science Letters, 435, 94-104

MAGGI, A. JACKSON, J., McKENZIE, D. \& PREISTLEY, K. 2000. Earthquake focal depths, effective elastic thickness and the strength of the continental lithosphere. Geology, 28, 495-498.

MAHÉO, G., GUILLOT, S., BLICHERT-TOFT, J., ROLLAND, Y. \& PÊCHER, A. 2002. A slab breakoff model for the Neogene thermal evolution of South Karakoram and South Tibet. Earth and Planetary Science Letters, 195, 45-58.

MECHIE, J., KIND, R. \& SAUL, J. 2011. The seismological structure of the Tibetan Plateau crust and mantle down to $700 \mathrm{~km}$ depth. Geological Society Special Publication, 353, 376384.

MECHIE, J. et al. 2012. Crustal and uppermost mantle velocity structure along a profile across the Pamir and southern Tien Shan as derived from project TIPAGE wide-angle sesimic data. Geophysical Journal International, 188 (2), 385-407. 
MOLNAR, P. \& STOCK, J.M. 2000. Slowing of India's convergence with Eurasia since 20 $\mathrm{Ma}$ and its implications for Tibetan mantle dynamics. Tectonics, 28 (3), http://dx.doi,org/10.1029/2008TC002271

MOLNAR, P., BURCHFIEL, B.C.,ZIYUN, Z., L’UANGYI, L., SHUJI, W. \& MINMIN, H. 1987. Geological evolution of northern Tibet: results of an expedition to Ulugh Muztagh. Science, 235, 299-305.

NABELEK, J., HETENYI, G. et al., 2009. Underplating in the Himalaya-Tibet collision zone revealed by the Hi-CLIMB experiment. Science, 325, 1371-1374.

NEGREDO, A.M., REPLUMAZ, A., VILLASENOR, A. \& GUILLOT, S. 2007. Modeling the evolution of continetal subduction processes in the Pamir-Hindu Kush region. Earth and Planetary Science Letters, 259, 212-225.

NISHIDAI, T. \& BERRY, J.L. 1990. Structure and Hydrocarbon potential of the Tarim Basin (NW China) from satellite imagery. Journal of Petroleum Geology, 13(1), 35-58.

PALIN, R.M., SEARLE, M.P., WATERS, D.J., HORSTWOOD, M.S.A. \& PARRISH, R.R. 2012. Combined thermobarometry and geochronology of peraluminous metapelites from the Karakoram metamorphic complex, North Pakistan; New insights into the tectonothermal evolution of the Baltoro and Hunza Valley regions. Journal of Metamorphic Geology, doi: 10.1111/j.1525-1314.2012.00999.x

PALIN, R.M., SEARLE, M.P., ST-ONGE, M.R., WATERS, D.J., ROBERTS, N.M.W., HORSTWOOD, M.S.A., PARRISH, R.R. \& WELLER, O.M. 2014. Two-stage cooling history of pelitic and semi-pelitic mylonite (sensu lato) from the Dongjiu-Milin shear zone, northwest flank of the eastern Himalayan syntaxis. Gondwana Research, http://dx/doi.org/10.1016/j.gr.2014.07.009

PARRISH, R.R. \& TIRRUL, R. 1989. U-Pb age of the Baltoro granite, northwest Himalaya, and implications for zircon inheritance and monazite U-Pb systematics. Geology, 17, 10761079 .

PAVLIS, T. \& DAS, S. 2000. The Pamir-Hindu Kush seismic zone as a strain marker for flow in the upper mantle. Tectonics, 19, 103-115.

PEGLER, G. \& DAS, S. 1998. An enhanced image of the Pamir-Hindu Kush seismic zone from relocated earthquake hypocenters. Geophysical Journal International, 134, 573-595.

PHILLIPS, R.J. \& SEARLE, M.P. 2007. Macrostructural and microstructural architecture of the Karakoram Fault: Relationship between magmatism and strike-slip faulting. Tectonics, 26 TC3017, doi:10.1029/2006TC001946

PREISTLEY, K., JACKSON, J. \& McKENZIE, D. 2008. Lithospheric structure and deep earthquakes beneath India, the Himalaya and southern Tibet. Geophysical Journal International, 172, 345-362.

QUIGLEY, M.C., LAINGJUN, Y., GREGORY, C., CORVINO, A., SANDIFORD, M., WILSON, C.J.L. \& XIAOHAN, L. 2008. U-Pb SHRIMP zircon geochronology and T-t-d history of the Kampa Dome, southern Tibet. Tectonophysics, 446, 97-113.

RAI, S., PREISTLEY, K., GAUR, V., MITRA, S., SINGH, M. \& SEARLE, M.P. 2006. Configuration of the Indian Moho beneath the Northwest Himalaya and Ladakh. Geophysical Research Letters, 33, doi:10.1029/2006GL026076. 
REX, A.J., SEARLE, M.P., TIRRUL, R., CRAWFORD, M.B., PRIOR, D.J. \& REX, D.C. 1988. The geochemical and tectonic evolution of the central Karakoram, north Pakistan. Philosophical Transactions of the Royal Society, London, A326, 229-255.

ROBINSON, A.C. 2009. Geologic offsets across the northern Karakoram fault: Implications for its role and terrane correlations in the western Himalayan-Tibetan orogen. Earth and Planetary Science Letters, 279, 123-130 doi:10.1016/j.epsl.2008.12.039

ROBINSON, A.C. 2015. Mesozoic tectonics of the Gondwanan terranes of the Pamir plateau. $\begin{array}{lllll}\text { Journal of Asian } & \text { Earth 170-179. }\end{array}$ http://dx.doi.org/10.1016/j.jseaes.2014.09.012

ROBINSON, A.C., YIN, A., MANNING, C.E., HARRISON, T.M., ZHANG, S-H. \& WANG, X-F. 2004. Tectonic evolution of the northeastern Pamir: constraints from the northern portion of Cenozoic Kongur extensional system. Geological Society of America Bulletin, 116, 953-974.

ROBINSON, A.C., YIN, A., MANNING, C.E., HARRISON, T.M., ZHANG, S-H. \& WANG, X-F. 2007. Cenozoic evolution of the eastern Pamir: implications for strain accommodation mechanisms at the western end of the Himalayan-Tibetan orogen. Geological Society of America Bulletin, 119, 882-896.

ROBINSON, A.C., DUCEA, M. \& LAPIN, T.J. 2012. Detrital zircon and isotopic constraints on the crustal architecture and tectonic evolution of the northeastern Pamir. Tectonics, 31, TC2016, doi: 10.1029/2011TC003013

ROLLAND, Y., MAHEO, G., GUILLOT, S. \& PÊCHER, A. 2001. Tectono-metamorphic evolution of the Karakoram Metamorphic Complex (Dassu-Askole area, NE Pakistan): exhumation of mid-crustal HT-MP gneisses in a convergent context. Journal of Metamorphic Geology, 19, 717-737.

RUTTE, D., RATSCHBACHER, L., SCHNEIDER, S., STÜBNER, K., STEARNS< M.A., GULZAR, M.A \& HACKER, B.R. 2017a. Building the Pamir-Tibet Plateau-Crustal stacking, extensional collapse, and lateral extrusion in the Central Pamir: 1. Geometry and kinematics, Tectonics, 36, 342-384, doi: 310.1002/TC004293.

RUTTE, D., RATSCHBACHER, L., KHAN, J., STÜBNER, K., HACKER, B.R., STEARNS, M.A., ENKELMANN, E., JONCKHEERE, J. R., PFÄNDER, A., SPERNER, B. \& TICHOMIROWA, M. 2017b. Building the Pamir-Tibet Plateau-Crustal stacking, extensional collapse, and lateral extrusion in the Central Pamir: 2. Timing and rates, Tectonics, 36, 385-419, doi: 310.1002/TC004294.

RUZENTSEV, S.V. \& SHVOLMAN, V.A. 1981. Tectonic zoning of the Pamir and Afghanistan, In: Sinha, A.K (Ed) Contemporary Geoscientific Researches in the Himalaya. Bishen Singh Mahendra Pal Singh, Dehra Dun, India.

SCHMIDT, J., HACKER, B.R., RATSCHBACHER, and 7 others, 2011. Cenozoic deep crust in the Pamir. Earth and Planetary Science Letters, 312, 411-421, doi: 10.1016/j.eps1.2011.10.034

SCHULTE-PELKUM, V., MONSALVE, G. SHEEHAN, A., PANDEY, M.R., SAPKOTA, S., BILHAM, R. \& WU. F. 2005. Imaging the Indian subcontinent beneath the Himalaya. Nature, 435, 1222-1225.

SCHWAB, M., RATSCHBACHER, L., SIEBEL, W., McWILLIAMS, M., MINAEV, V., LUTKOV, V., CHEN, F., STANEK, K., NELSON, B., FRISCH, W. \& WOODEN, J.L. 
2004. Assembly of the Pamirs: age and origin of magmatic belts from the southern Tien Shan and southern Pamirs and their relation to Tibet. Tectonics, 23. doi:10.1029/2003TC001583

SCHNEIDER, F.M., YUAN, X., SCHURR, B. et al. 2013. Seismic imaging of subducting continental lower crust beneath the Pamir. Earth and Planetary Science Letters, 375, 101112.

SEARLE, M.P. 1991. Geology and Tectonics of the Karakoram Mountains: Chichester, John Wiley and Sons, pp. 358. with Geological Map of the Central Karakoram Mountains, scale 1: 250,000

SEARLE, M.P. 2010. Low-angle normal faults in the compressional Himalayan orogen: Evidence from the Annapurna-Dhaulagiri Himalaya, Nepal. Geosphere, 6, 296-315.

SEARLE, M.P. 2015. Mountain Building, Tectonic Evolution, Rheology, and Crustal Flow in the Himalaya, Karakoram and Tibet. In: Treatise on Geophysics, Second Edition, 6, 469511, http://dx.doi.org/10.1016/B978-0-444-53802-4.00121-4

SEARLE, M.P. \& KHAN, M.A. 1996. Geological Map of North Pakistan, scale 1:250,000. Dept. Earth Sciences, Oxford University, UK.

SEARLE, M.P. \& TIRRUL, R. 1991. Structural and thermal evolution of the Karakoram crust. Journal of the Geological Society, London, 148, 65-82.

SEARLE, M.P., REX, A.J., TIRRUL, R., REX, D.C., \& BARNICOAT, A. 1989. Metamorphic, magmatic and tectonic evolution of the Central Karakoram in the Biafo-Hushe regions of N. Pakistan. Geological Society of America, Special Paper, 232, 47-74.

SEARLE, M.P., PARRISH, R.R., TIRRUL, R. \& REX, D.C. 1990. Age of crystallisation and cooling of the K2 gneiss in the Baltoro Karakoram. Journal of the Geological Society, London, 147, 603-606.

SEARLE, M.P., CRAWFORD, M.B. \& REX, A.J. 1992. Field relations, geochemistry, origin and emplacement of the Baltoro granite, central Karakoram. Transactions of the Royal Society of Edinburgh, 83, 519-538.

SEARLE, M.P., CORFIELD, R.I., STEPHENSON, B.J. \& McCARRON, J. 1997. Structure of the North Indian continetal margin in the Ladakh-Zanskar Himalaya: Implications for the timing of obduction of the Spontang ophiolite, India-Asia collision and deformation events in the Himalaya. Geological Magazine, 134, 297-316.

SEARLE, M.P., WEINBERG, R. \& DUNLAP, W.J. 1998. Transpressional tectonics along te Karakoram Fault zone, northern Ladakh: constraints on Tibetan extrusion. In: HOLDSWORTH, R.W., STRACHAN, R.A. \& DEWEY, J.F. (Eds) Continental Transpresional and Transtensional Tectonics. Geological Society, London, Special Publication, 135, 307-326.

SEARLE, M.P., HACKER, B.R. \& BILHAM, R. 2001. The Hindi Kush seismic zone as a paradigm for the creation of Ultrahigh pressure diamond- and coesite-bearing continental rocks. Journal of Geology, 109, 143-153.

SEARLE, M.P., LAW, R.D. \& JESSUP. M.J. 2006. Crustal structure, restoration and evolution of the Greater Himalaya in Nepal-South Tibet: implications for channel flow and ductile extrusion of the middle crust. In: Law, R.D., Searle, M.P. \& Godin, L. (Eds) Channel Flow, Ductile Extrusion and Exhumation in Continental collision zones. Geological Society, London, Special Publication 268, 355-378. 
SEARLE, M.P., COTTLE, J.M., STREUlE, M.J. \& WATERS, D.J. 2010a. Crustal melt granites and migmatites along the Himalaya: melt source, segregation, transport and granite emplacement mechanisms. Transactions of the Royal Society of Edinburgh, Earth Sciences, 100, 219-233. Doi: 10.1017/S175569100901617X

SEARLE, M.P., PARRISH, R.R., THOW, A.V., NOBLE, S.R., PHILlIPS, R.J. \& WATERS, D.J. 2010b. Anatomy, age and evolution of a collisional mountain belt: the Baltoro granite batholith and Karakoram Metamorphic Complex, Pakistani Karakoram. Journal of Geological Society, London, 167, 183-202, doi:10.1144/0016-76492009-043

SEARLE, M.P., ELLIOTT, J.R., PHILIPS, R.J. \& CHUNG, S-L. 2011. Crustal-lithospheric structure and continental extrusion of Tibet. Journal of Geological Society, London, 168, 633-672, doi:10.1144/0016-76492010-139

SEARLE, M.P., ROBERTS, N.M.W., CHUNG, S-L., LEE, Y-H., COOK, K.L., ELLIOTT, J.R., WELlER, O.M., ST-ONGE, M.R., XU, X-W., TAN, X-B. \& LI, K. 2016. Age and anatomy of the Gongga Shan batholith, eastern Tibetan Plateau, and its relationship to the active Xianshui-he fault. Geosphere, 12, (3), doi:10.1130/GES01244.1

SENGÖR, A.M.C., NATAL'IN, B.A. \& BURTMAN, V.S. 1993. Evolution of the Altaid tectonic collage amd Palaeozoic crustal growth in Eurasia. Nature, 364, 299-307.

SHAFFER, M., HACKER, B.R., RATSCHBACHER, L., \& KYLANDER-CLARK, A.R.C. 2017. Foundering triggered bby collision of India and Asia captured in xenoliths. Tectonics 36, https://doi.org/10/1002/2017TC004704

SHARMA, R.S. 2009. Cratons and Fold Belts of India. Springer-Verlag, Berlin, Heidelberg, doi: 10.1007/978-3-642-021459-8

SMIT, M.A., HACKER, B.R. \& LEE, J. 2014a. Tibetan garnet records early Eocene initiation of thickening in the Himalaya. Geology, 42, (7), 591-594, doi: 10.1130/G35524.1

SMIT, M.A., RATSCHBACHER, L., KOOIJMAN, E. \& STEARNS, M.A. 2014b. Early evolution of the Pamir deep crust from Lu-Hf and U-Pb geochronology and garnet thermometry. Geology, 42, (12), 1047-1050, doi: 10.1130/G35878.1

SOBEL, E.R. \& DUMITRU, T.A. 1997. Thrusting and exhumation around the margins of the western Tarim Basin during the India-Asia collision. Journal of Geophysical Research, 102(B3) 5043-5063.

SOBEL E.R. et al. 2011. Late Mioceme-Pliocene deceleration of dextral slip between Pamir and Tarim: implications for Pamir orogenesis. Earth and Planetary Science Letters, 304, 369378. Doi: $10.1016 /$ j.eps1.2011.02.012

STEARNS, M.A., HACKER, B.R., RATSCHBACHER, L., LEE, J., COTTLE, J.M., \& KYLANDER-CLARK, A. 2013. Synchronous Oligocene-Miocene metamorphism of the Pamir and the north Himalaya driven by plate-scale dynamics. Geology, 41, doi: $10.1130 / \mathrm{G} 34451.1$

STEARNS, M.A., HACKER, B.R., RATSCHBACHER, L., RUTTE, D., \& KYLANDERCLARK, A. 2015. Titanite petrochronology of the Pamir gneiss domes: implication for middle to deep crust exhumation and titanite closure to $\mathrm{Pb}$ and $\mathrm{Zr}$ diffusion. Tectonics, 34, 784-802, doi:10.1002/2014TC003774 
ST-ONGE, M.R., RAYNER, N. \& SEARLE, M.P. 2010. Zircon age determination for the Ladakh batholith at Chumatang (Northwest India): implication for the age of the India-Asia collision in the Ladakh Himalaya. Tectonophysics, 495, 171-183.

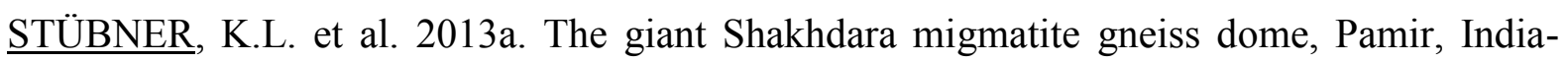
Asia collision zone, 1. Geometry and kinematics. Tectonics, 32, 948-979, doi: 10.1029/95TC00927

STÜBNER, K.L. et al. 2013b. The giant Shakhdara migmatite gneiss dome, Pamir, IndiaAsia collision zone, 2. Timing of dome formation. Tectonics, 32, 1404-1431, doi: $10.1002 /$ tect20059

THOMPSON, J., BURBANK, D.W., LI, T., CHEN, J. \& BOOKHAGEN, B. 2015. Late Miocene northward propagation of the northeast Pamir Thrust system, northwest China. Tectonics, 34, 510-534, doi:10.1002/2014TC003690

TILMANN, F., NI, J. et al., 2003. Seismic imaging of the downwelling Indian lithosphere beneath Central Tibet. Science, 300, 1424-1427.

Van HINSBERGEN, D.J.J., KAPP, P., DUPONT-NIVET, G., LIPERT, P.C., DeCELLES, P., \& TORSVICK, T.H. 2011. Restoration of Cenozoic deformation in Asia and the size of Greater India. Tectonics, 30, TC5003, doi: 10.1029/2011TC002908

VLASOV, N.G., DYAKOV, Y.A. \& CHEREV, E.S. 1991. Geological Map of the Tajik SSR and adjacent territories, 1:500,000, Leningrad.

WELLER, O.M., ST-ONGE, M.R., RAYNER, N., SEARLE, M.P. \& WATERS, D.J. 2015. Miocene magmatism in the Western Nyainqentanglha mountains of southern Tibet: An exhumed bright spot? Lithos, doi: http://dx.doi.org/10.1016/j.lithos.2015.06.024

WINDLEY, B.F. 1977. The Evolving Continents. John Wiley and sons, Chichester.

WHITTLINGER, G., VERGNE, J. TAPPONNIER, P. ET AL. 2004. Teleseismic imaging of subducting lithosphere and Moho offsets beneath western Tibet. Earth and Planetary Science Letters, 221, 117-130.

YANG, W-Q., LIU, L., CAO, Y-T., WANG, C., HE, S-P., LI, R-S \& ZHU, X-H. 2010. Geochronological evidence of Indosinian (high-pressure) metamorphic event and its tectonic significance in Taxkorgan area of Western Kunlun Mountains, NW China. Science China, 53, 1445-1459.

YIN, A. \& HARRISON, T.M. 2000. Geological evolution of the Himalayan-Tibetan orogen. Annual Reviews of Earth and Planetary Sciences, 28, 211-280.

ZHAI, M-G. 2011. Cratonization and the anciuent North China Continent: a summary and review. Science China, Earth Sciences, 54, 1110-1120, doi:10.1007/s11430-011-4250-x

ZHU, B., KIDD, W.S.F., ROWLEY, D.B., CURRIE, B.S. \& SHAIFIQUE, N. 2005. Age of initiation of the India-Asia collision in the east-central Himalayas. Journal of Geology, 113, 265-285.

ZUBOVICH, A., SCHONE, T., METZGER, S., MOSIENKO, O., MUKHAMEDIEV, S.. SHAHSHEBAEV, A. \& ZACH, C. 2016. Tectonic interaction betweem the Pamir and Tien Shan observed by GPS. Tectonics, 35, 283-292, doi:10.1002/2015TC004055 


\section{Figure Captions}

Figure 1. Photo of the Pamir-Karakoram 'knot' looking east, taken from the International Space station (courtesy Tim Peake, and NASA).

Figure 2. Digital Elevation Model for the Pamir 'knot' showing the major mountain ranges of the Pamir, Hindu Kush, Karakoram, Himalaya and the Tarim and Tadjik basins. DEM is 30-arcsecond topography from GTOPO30 DEM; data available from US Geological Survey: https://lta.cr.usgs.gov/citation

Figure 3. Simplified geological map of the Pamir-Karakoram-western Tibet region showing major terranes, suture zones and faults.

Figure 4. Geological cross-sections across (a) Western Himalaya-Ladakh-Karakoram-Pamir profile and (b) across Central Himalaya and southern Tibet, showing major crustal units and structure, after Searle et al. (2011).

Figure 5. Geological map of the central Karakoram after Searle (1991), Searle and Tirrul (1991) and Searle et al. (2010b) showing compilation of all U-Pb ages from across the region.

Figure 6. Cross-sections of the Baltoro Karakoram, after Searle et al., (2010b).

Figure 7. Cliff profile in the Hushe valley, Pakistan Karakoram illustrating some intrusive relationships of pre-collisional Hushe gneisses intruded by main K7 (Baltoro) granite and leucogranite dykes and cut by a thin lamprophyre dyke. A summary of known U-Pb ages of the major granitic intrusions in the Baltoro and Hunza Karakoram is shown on the right.

Figure 8. Hunza leucogranite dykes, showing two main sets, north of Karimabad. U-Pb ages from Fraser et al. (2001).

Figure 9. Middle Miocene leucogranite dykes intruding the Oligocene-Early Miocene Karakoram metamorphic complex, Askole, Braldu valley.

Figure 10. Southern margin of the Baltoro granite batholith showing Miocene leucogranites with numerous xenoliths of sillimanite- and kyanite-grade gneisses, NE margin of Biafo glacier, Latok range; Conway's Ogre peak in background.

Figure 11. Early Miocene (20-13 Ma) leucogranites of the Trango Towers and Nameless Spire, Baltoro glacier, central Karakoram.

Figure 12. Summary of U-Pb zircon and monazite age data from the Karakoram granites from the Hunza valley, Baltoro glacier and Hushe valley regions of north Pakistan; data from Parrish and Tirrul (1989), Searle et al. (1990, 1991, 2010), Fraser et al. (2001) and Palin et al. (2012).

Figure 13. P-T paths and ages best tied to P-T conditions for the Cenozoic Pamir gneiss domes. See text for sources of data. 
Figure 14. Geochronology of Pamir gneiss domes or metamorphic core complexes. See text for sources of data.

Figure 15. Integrated geological cross-section across the Western (Pakistan) Himalaya, Kohistan arc, Karakoram and Pamir terranes showing large-scale structure. Major suture zones are in blue. The approximate outline of the Hindu Kush and Pamir seismic zones are in grey. The hatched orange region is the source zone of alkali magmatism for the Dunkeldik aand Taskurgan alkali volcanic field in the Pamir and the Karakoram lamprophyre dykes in Pakistan.

Figure 16. Time chart showing range of $\mathrm{U} / \mathrm{Th}-\mathrm{Pb}$ zircon and monazite geochronological data across the Asian plate (Pamir-Hindu Kush-Karakoram and Tibet). Left column shows data from the Indian plate Himalaya. Blue bars show Tethyan sedimentation with major unconformities. Pale green bars show age ranges for eclogite, kyanite and sillimanite grade metamorphism. For Asian plate rocks, dark green bars show range of ages for 'peak' metamorphism in staurolite (st), kyanite (ky) and sillimanite (sill) grade gneisses. Red bars show age ranges of crystallization of granites. Mauve bars show age ranges of potassic and ultra-potassic volcanic and intrusive rocks including adakites, shoshonites and trachytes. See text for sources of data. 


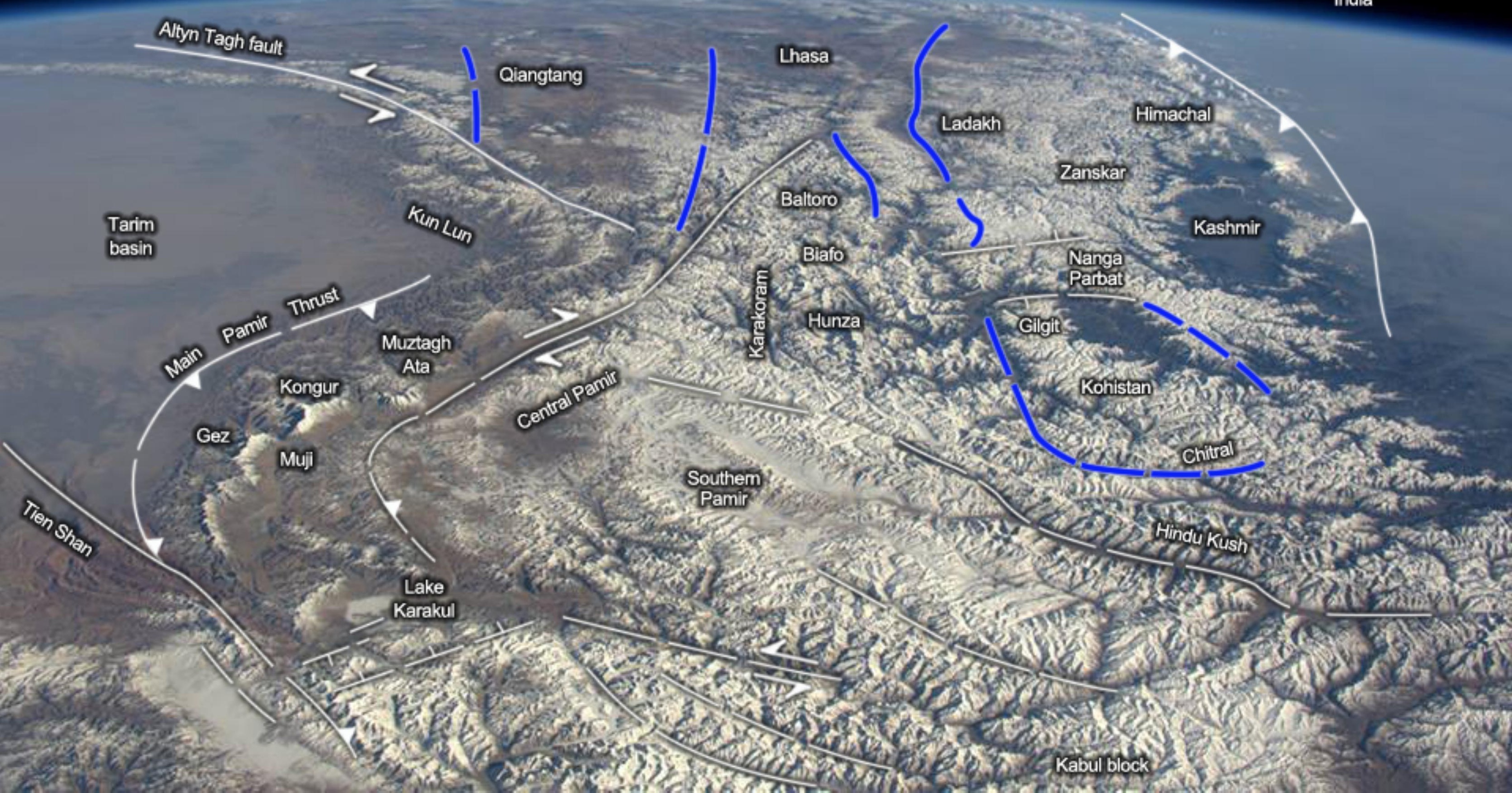




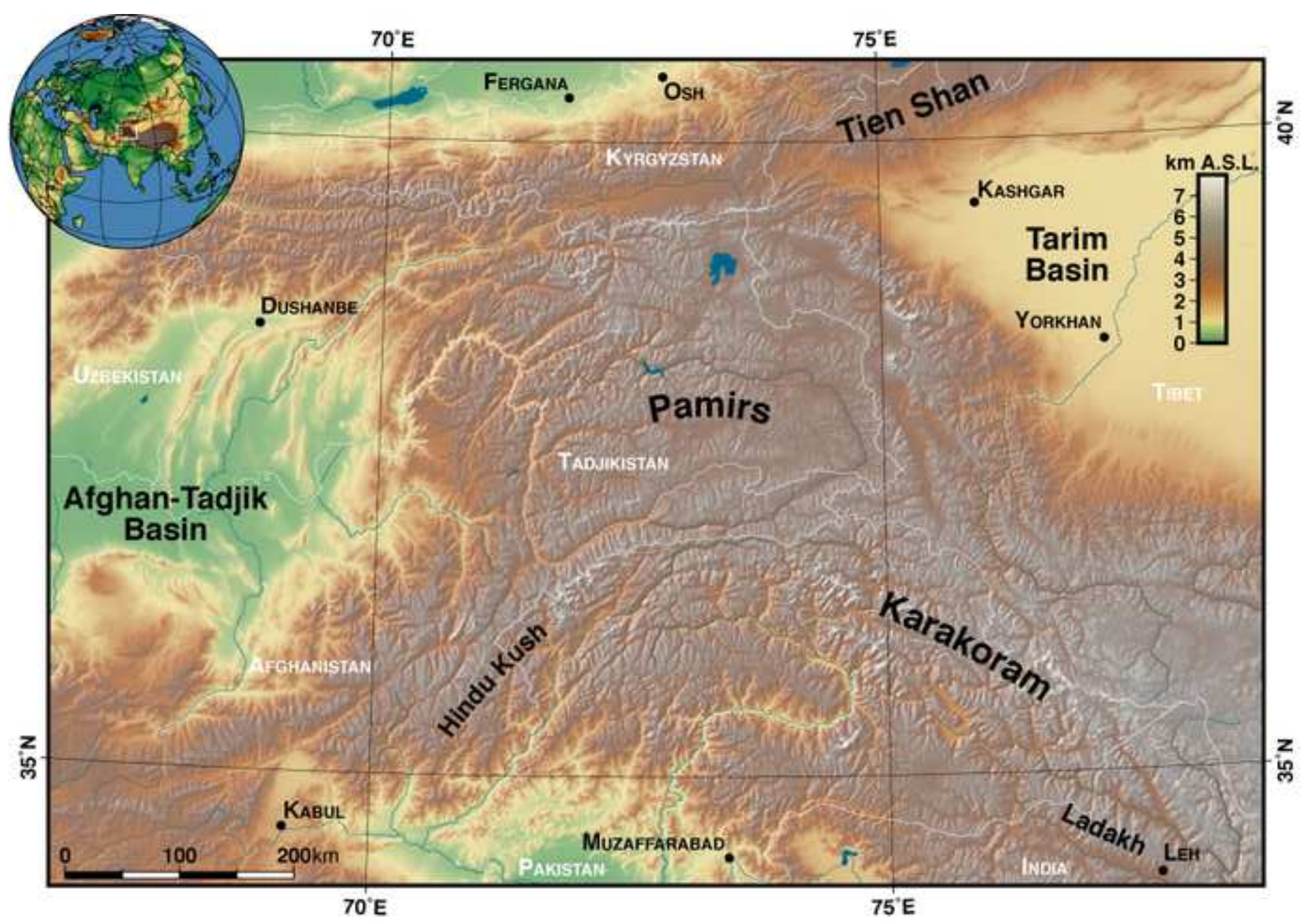


INDIAN PLATE - HIMALAYA

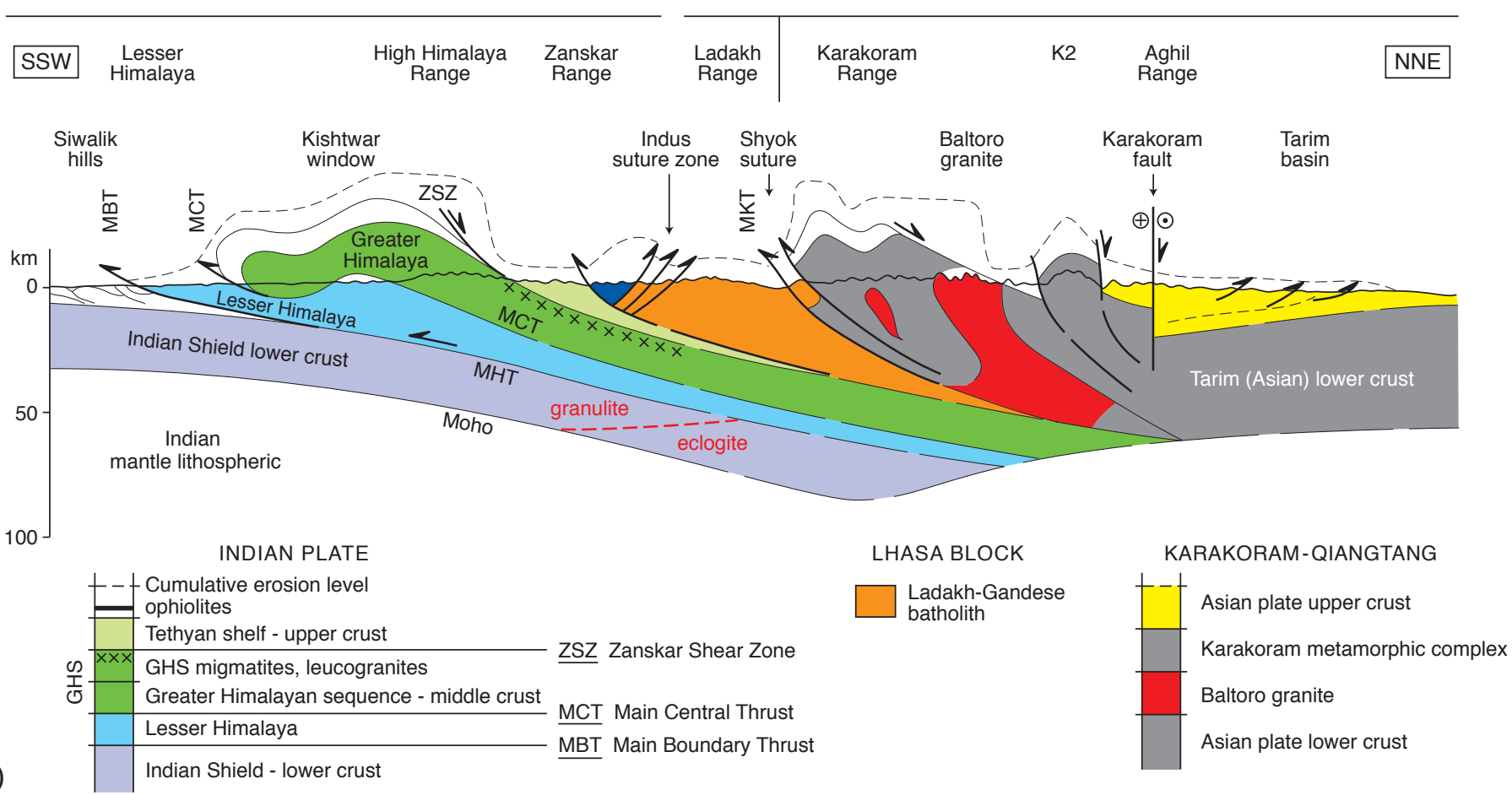

s
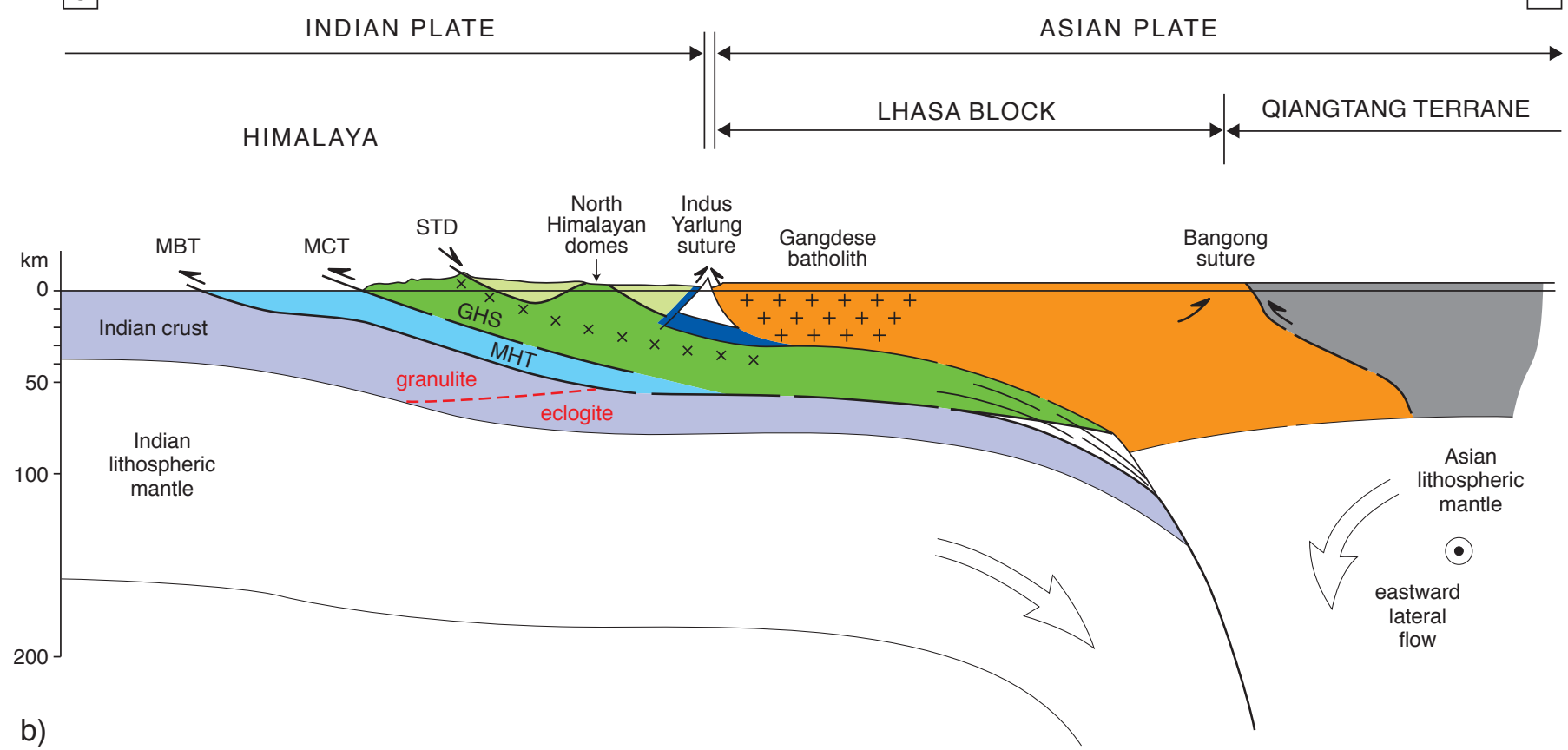


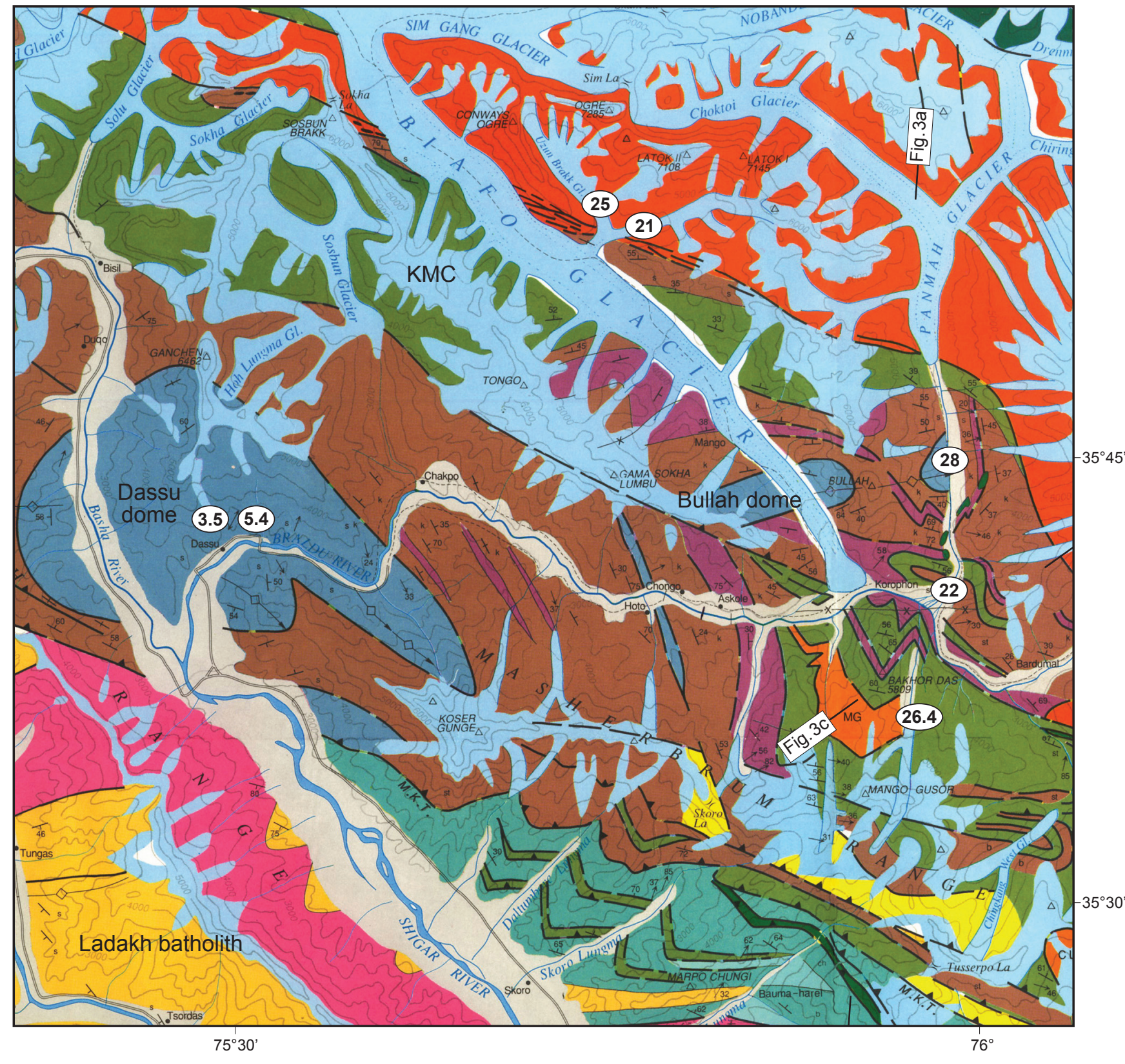

KARAKORAM METAMORPHIC COMPLEX

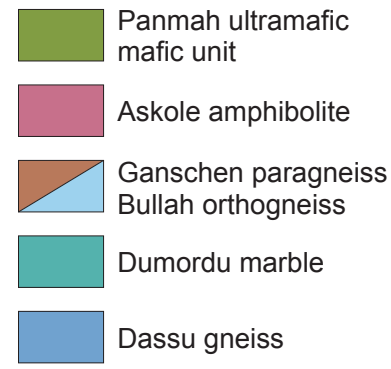

(28) U-Pb age
BALTORO GRANITES

MG Mango Gusar

$\mathrm{CL}$ Chinkiang-la granites

Baltoro granites

Masherbrum gneiss

\begin{tabular}{|l|l}
$\mathrm{K} / \mathrm{H}$ & $\begin{array}{l}\text { Kande orthogneiss } \\
\text { Hushe orthogneiss }\end{array}$
\end{tabular}

0

5

$10 \mathrm{~km}$
NORTHERN KARAKORAM

Aghil Fm. (Tr. - Jr.)

Shaksgam Fm. (Pm.)

Baltoro Fm. (Carb.)
black shales

Doksam schists Mitre aureole

Muztagh Tower gneiss

Broad Peak quartzite diorite

Fig. 2 (left) 

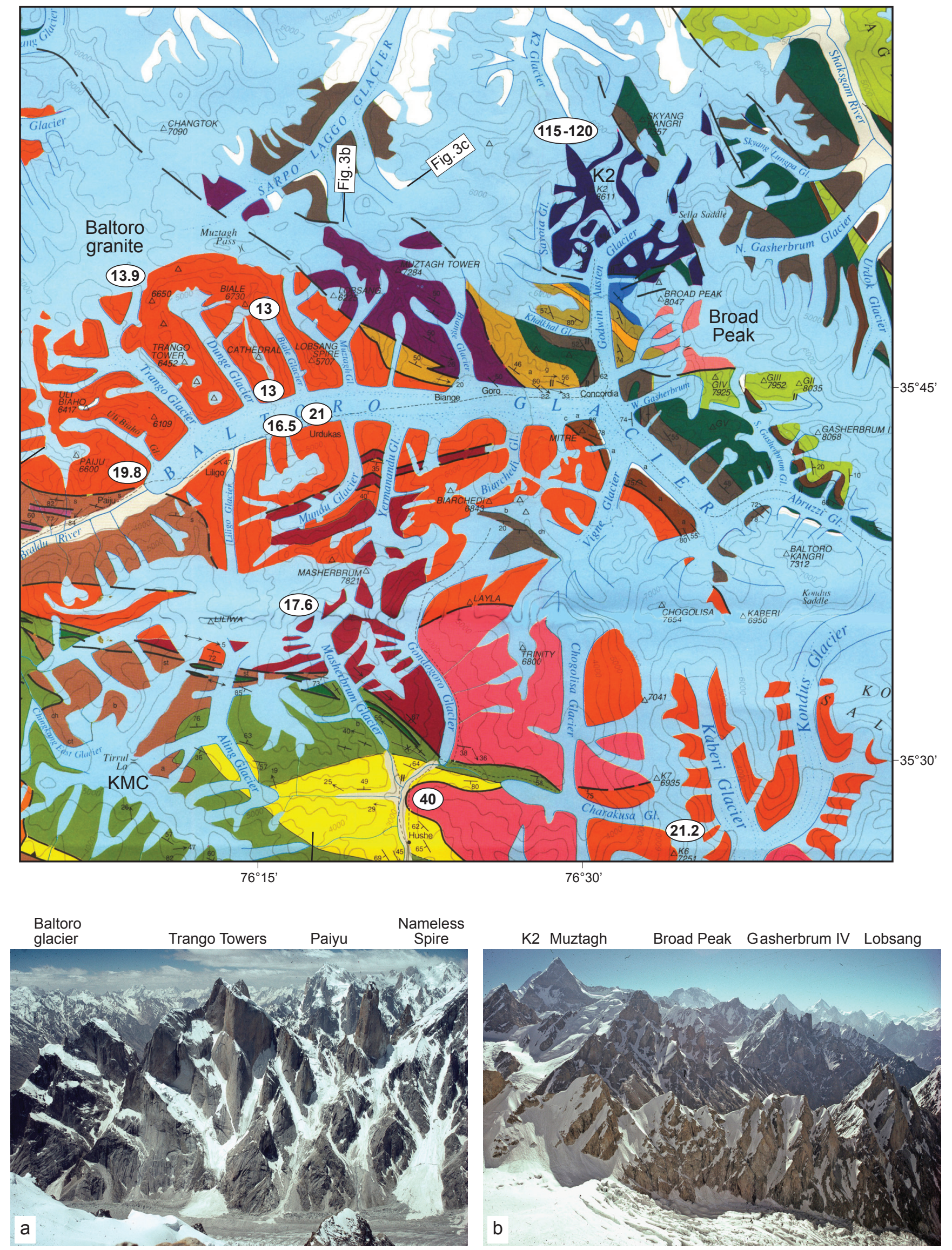

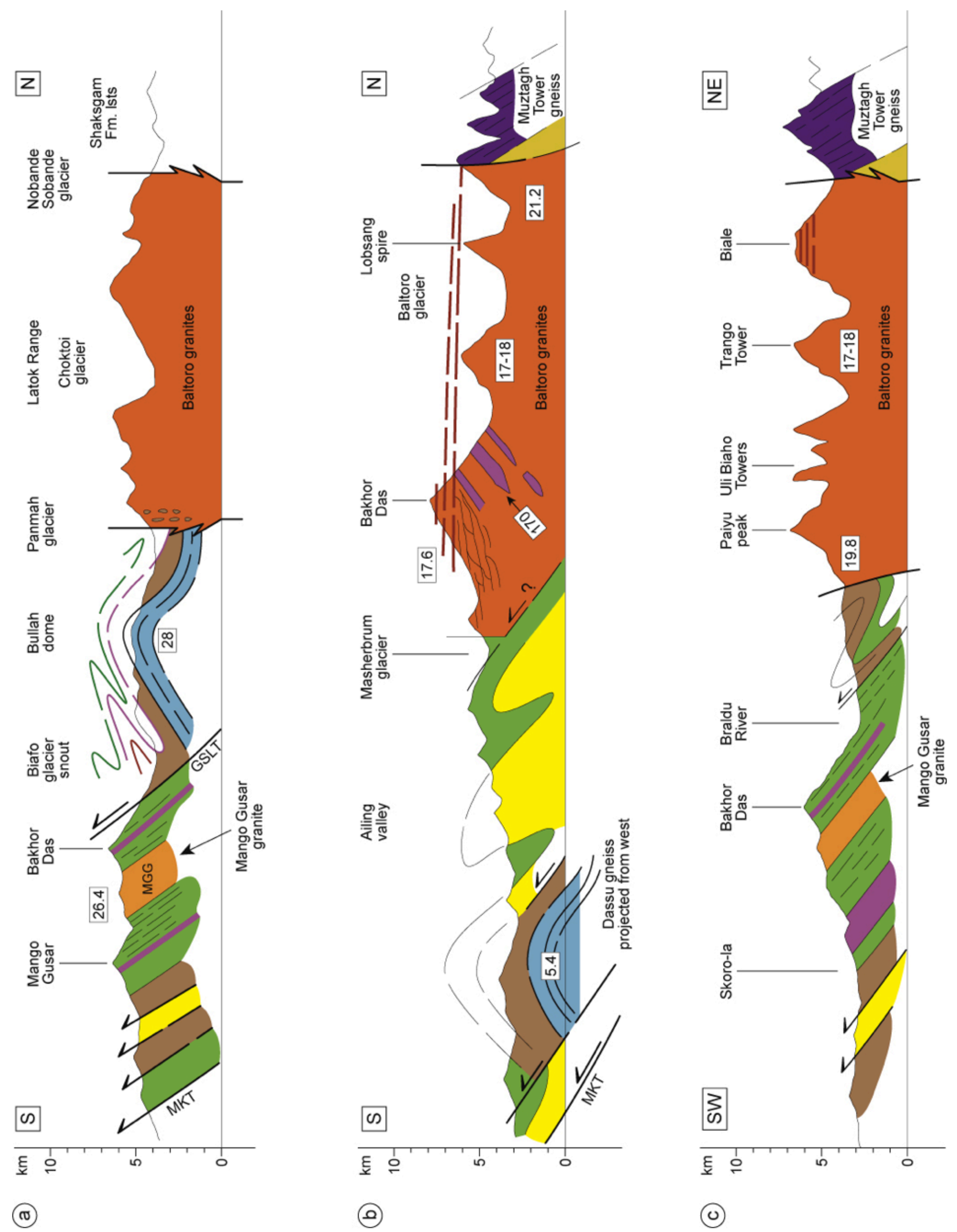

(ఠ)

() 


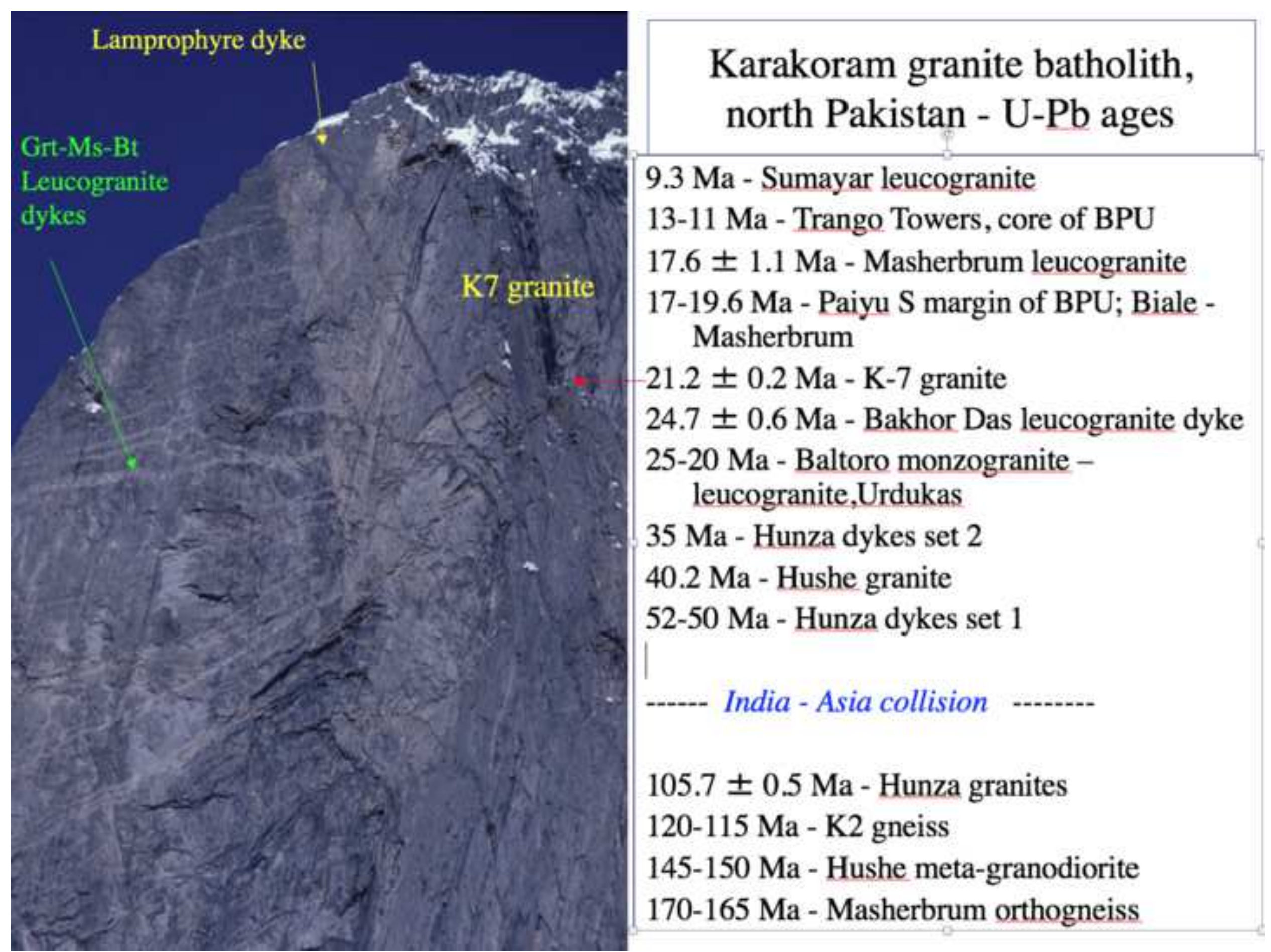

Karakoram north Pakistan - U-Pb ages

9.3 Ma - Sumayar leucogranite

13-11 Ma - Trango Towers, core of BPU

$17.6 \pm 1.1 \mathrm{Ma}$ - Masherbrum leucogranite

7-19.6 Ma - Paiyu S margin of BPU; Biale Masherbrum

$21.2 \pm 0.2 \mathrm{Ma}-\mathrm{K}-7$ granite

$24.7 \pm 0.6 \mathrm{Ma}$ - Bakhor Das leucogranite dyke

leucogranite,Urdukas

$35 \mathrm{Ma}$ - Hunza dykes set 2

$40.2 \mathrm{Ma}$ - Hushe granite

52-50 Ma - Hunza dykes set 1

India - Asia collision

$105.7 \pm 0.5 \mathrm{Ma}-$ Hunza granites

20-115 Ma - K2 gneiss

170-165 Ma - Masherbrum orthogneiss 


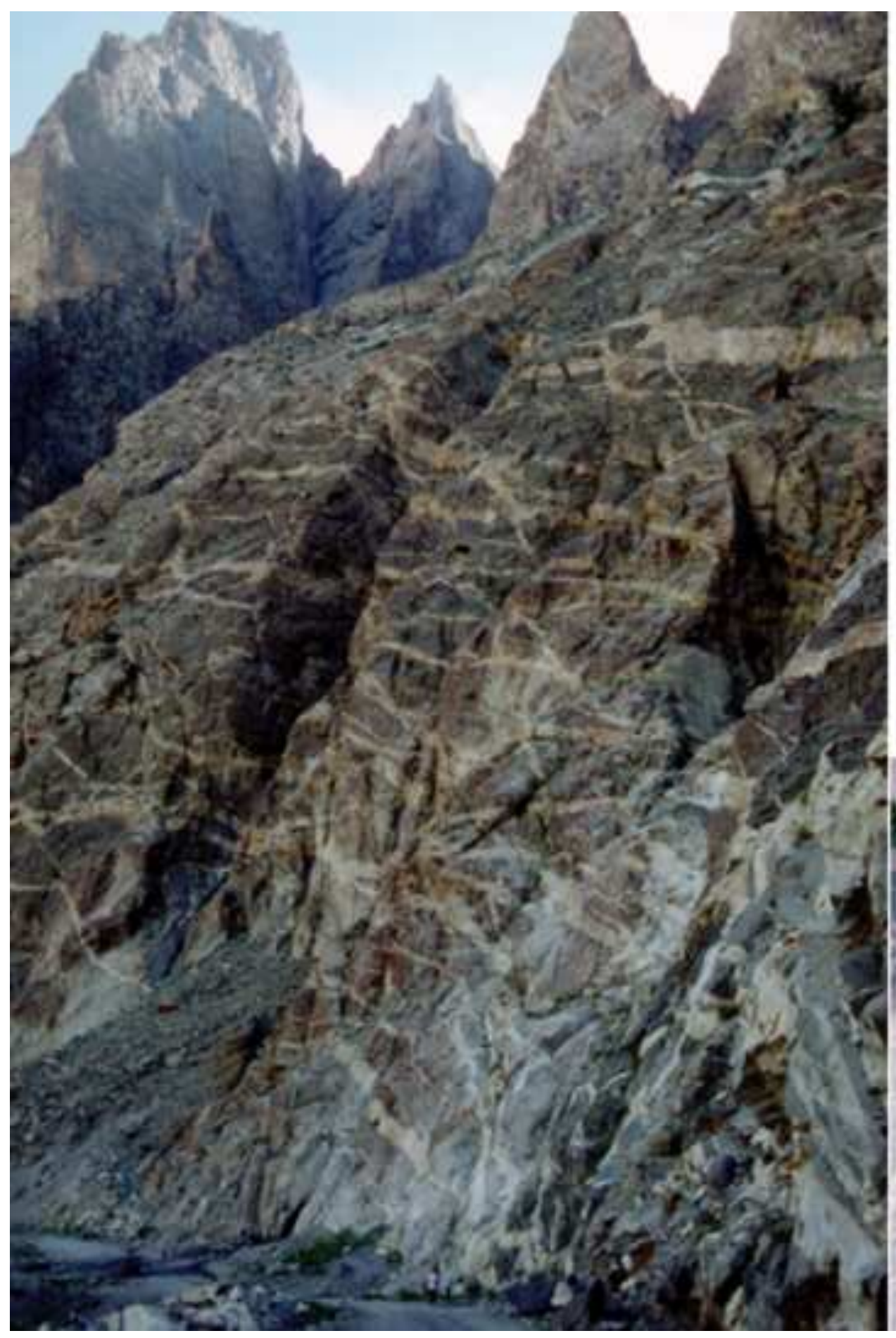

\section{Hunza dykes}

Set 1 deformed leucogranite sill Zircons 50-52 Ma

Set 2 cross-cutting leucogranite dyke Zircon, monazite $35.0 \pm 1.0 \mathrm{Ma}$

Main deformation fabric pre-35 Ma

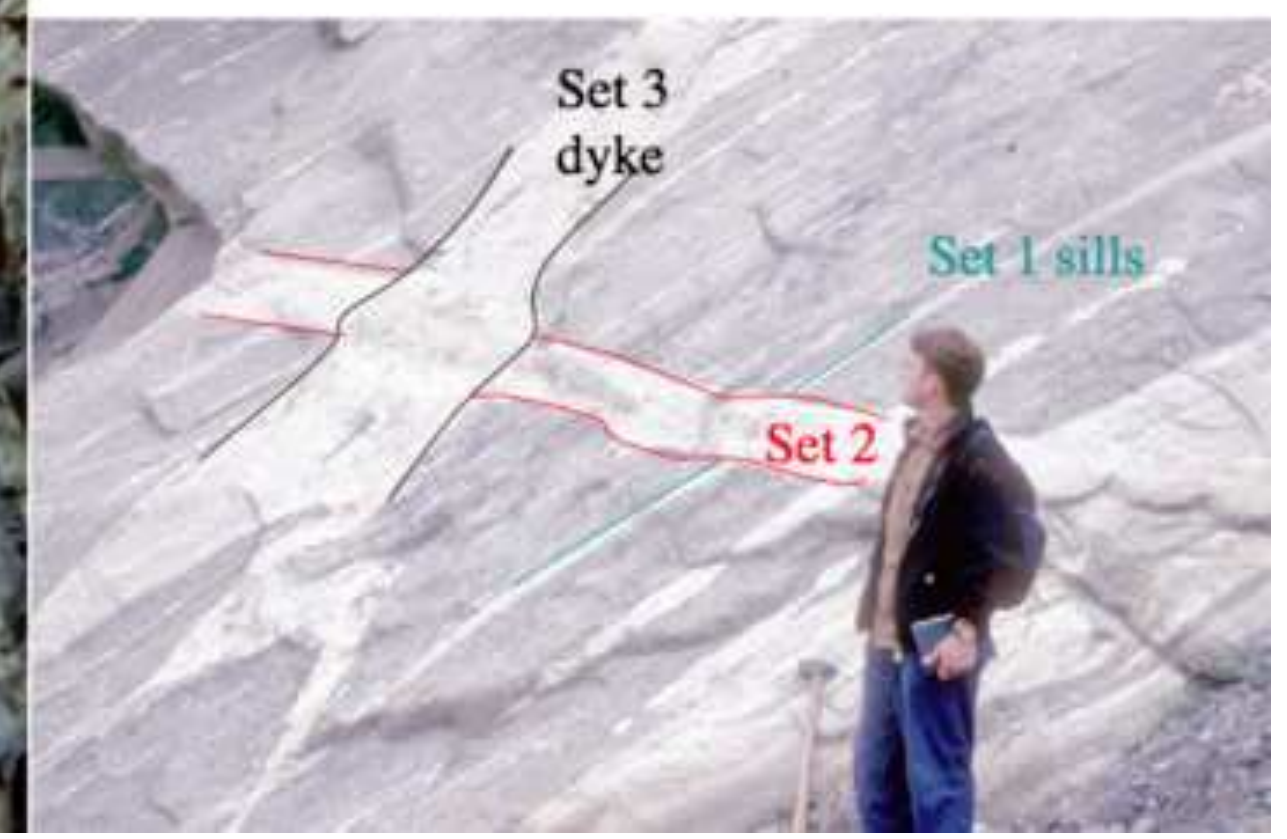




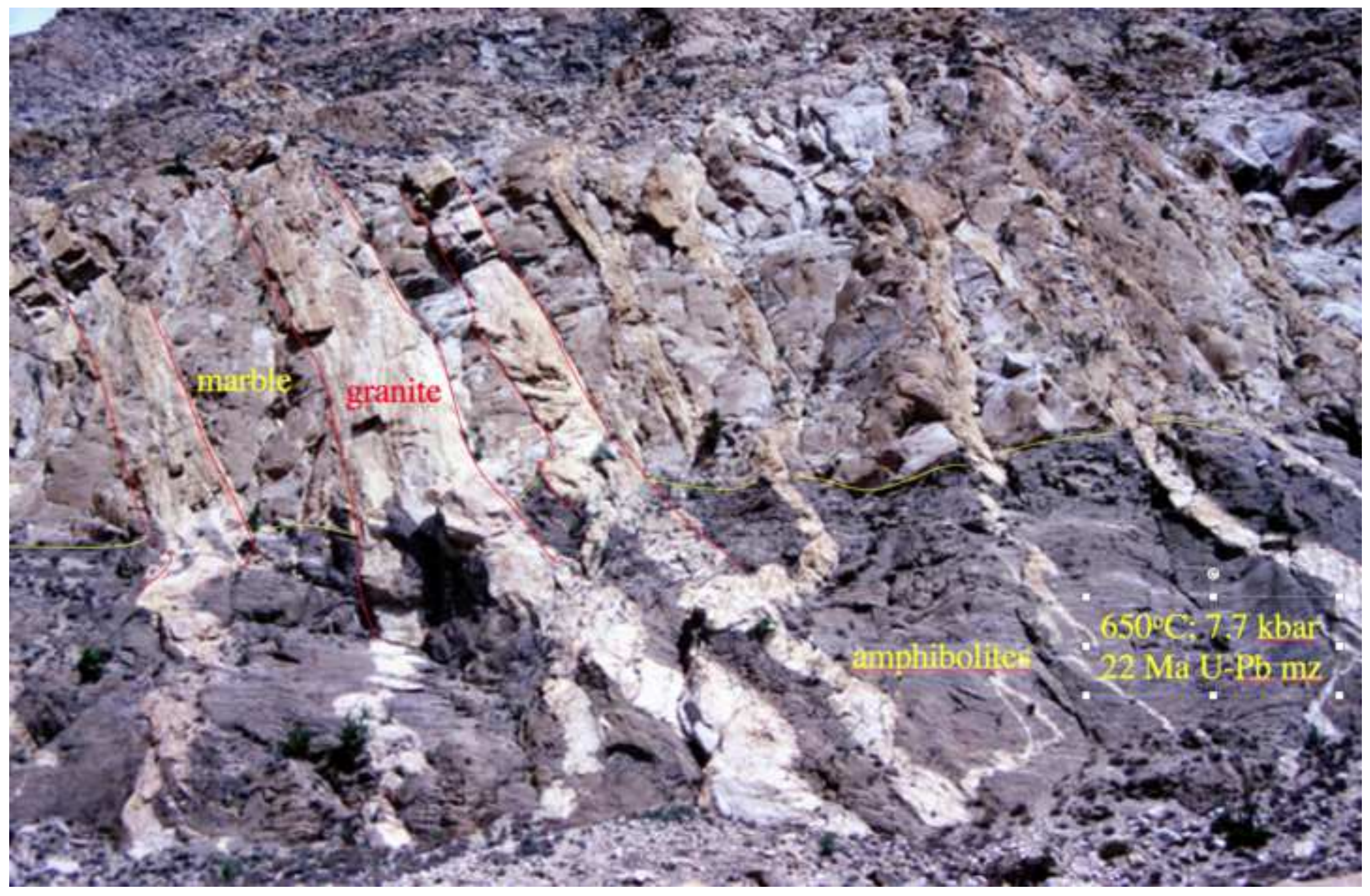



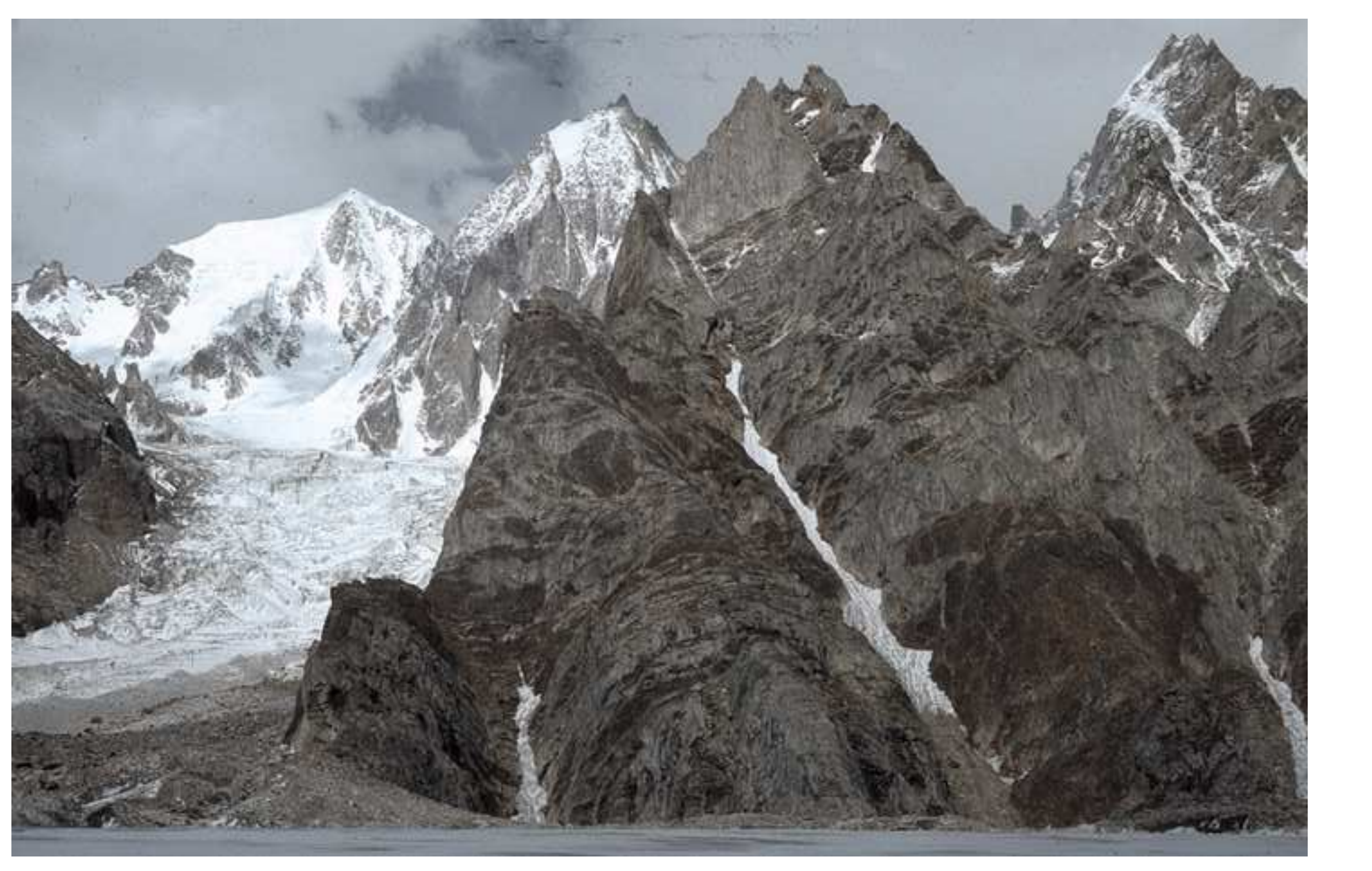

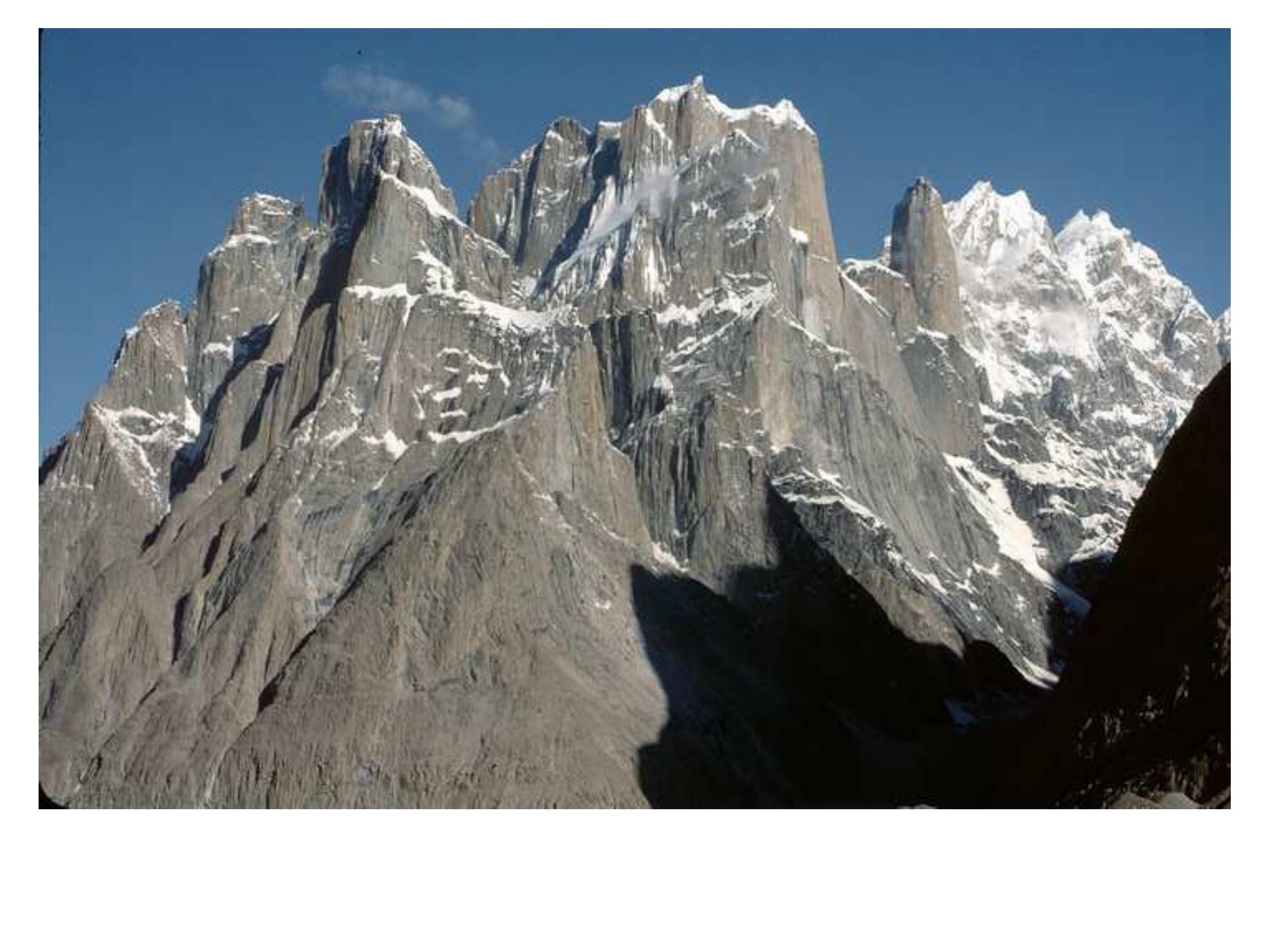


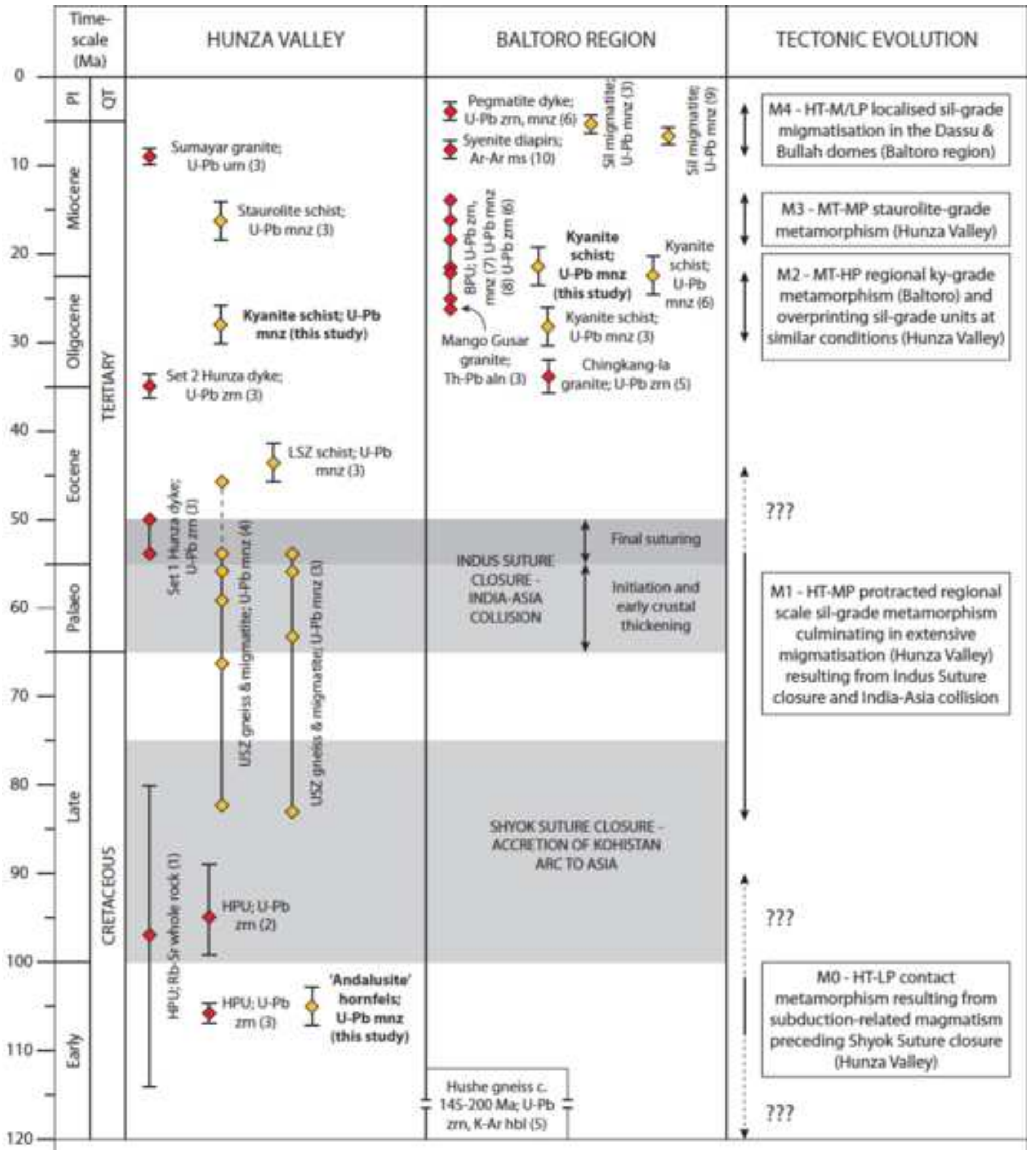




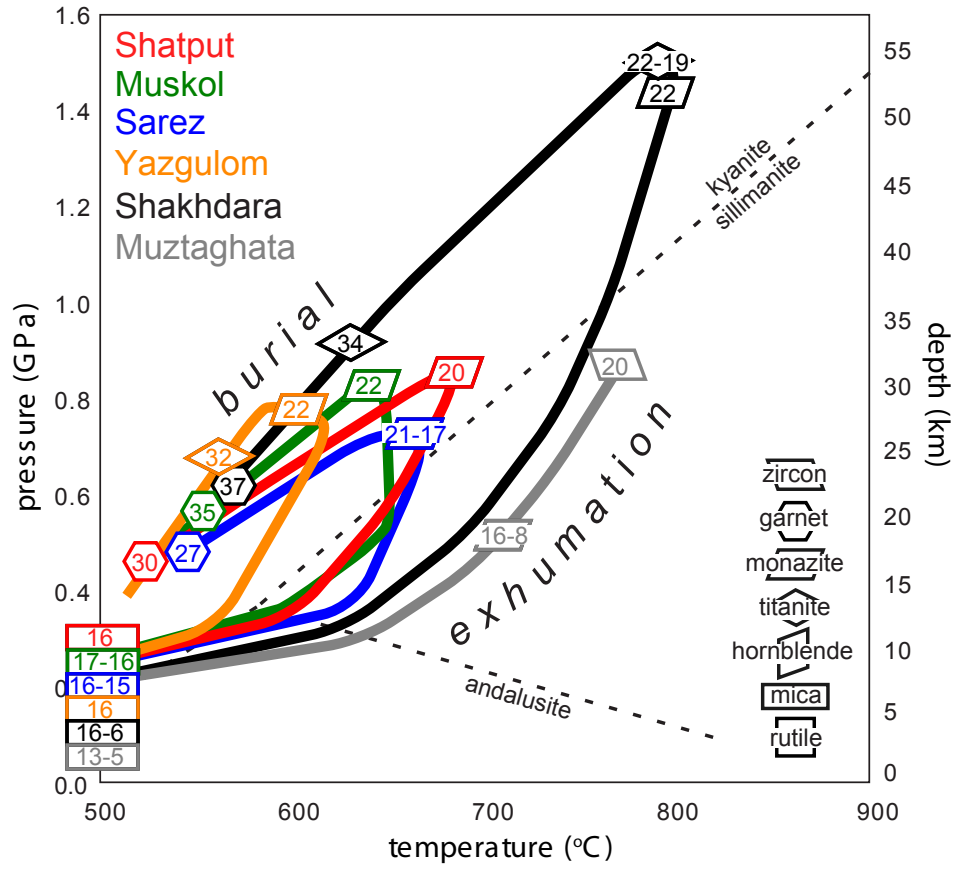

P-T paths and dates best tied to P-T conditions for Pamir Cenozoic domes. Data summarized in Cai et al. (2017) and Hacker et al. (2017) 


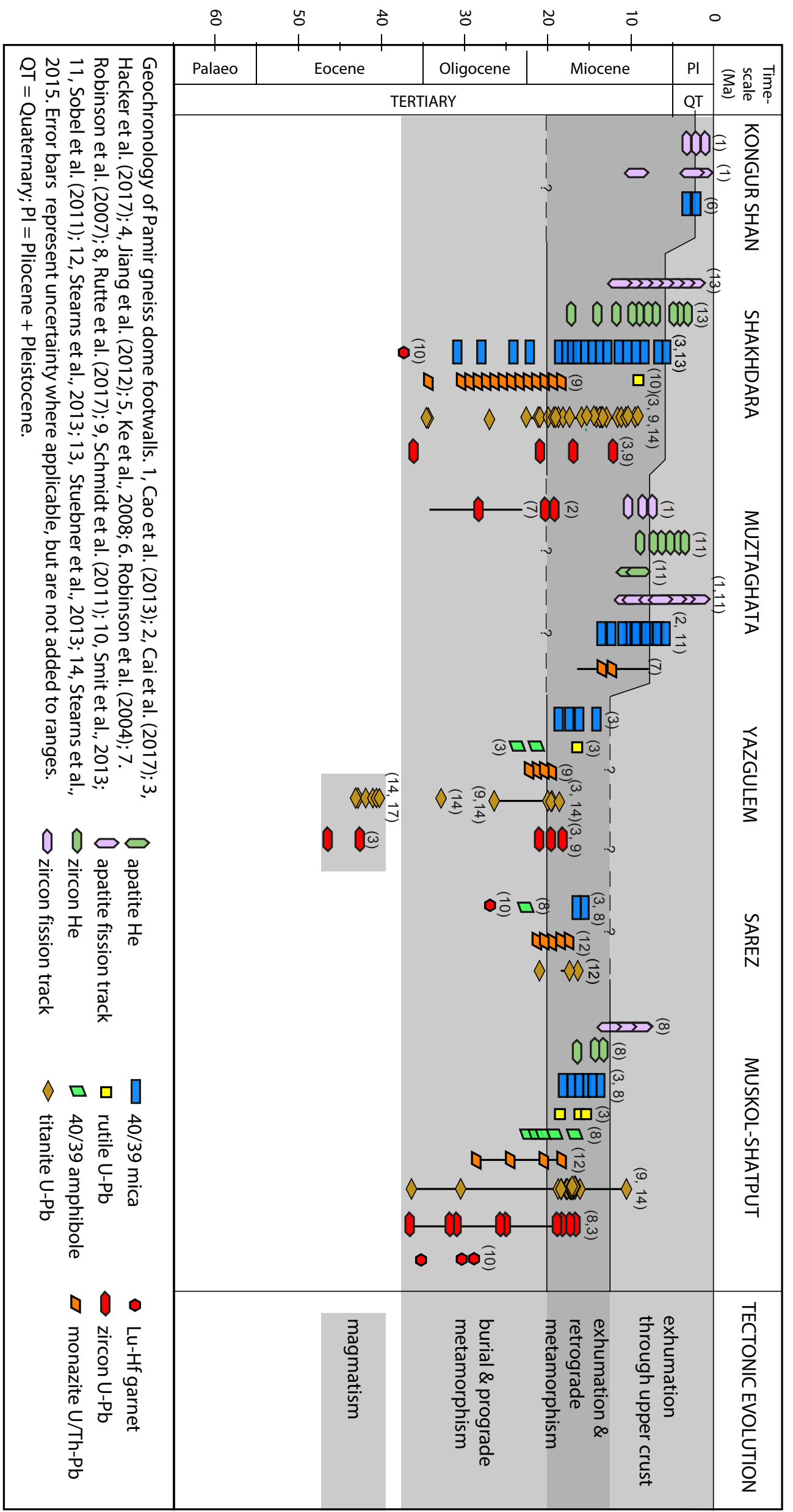




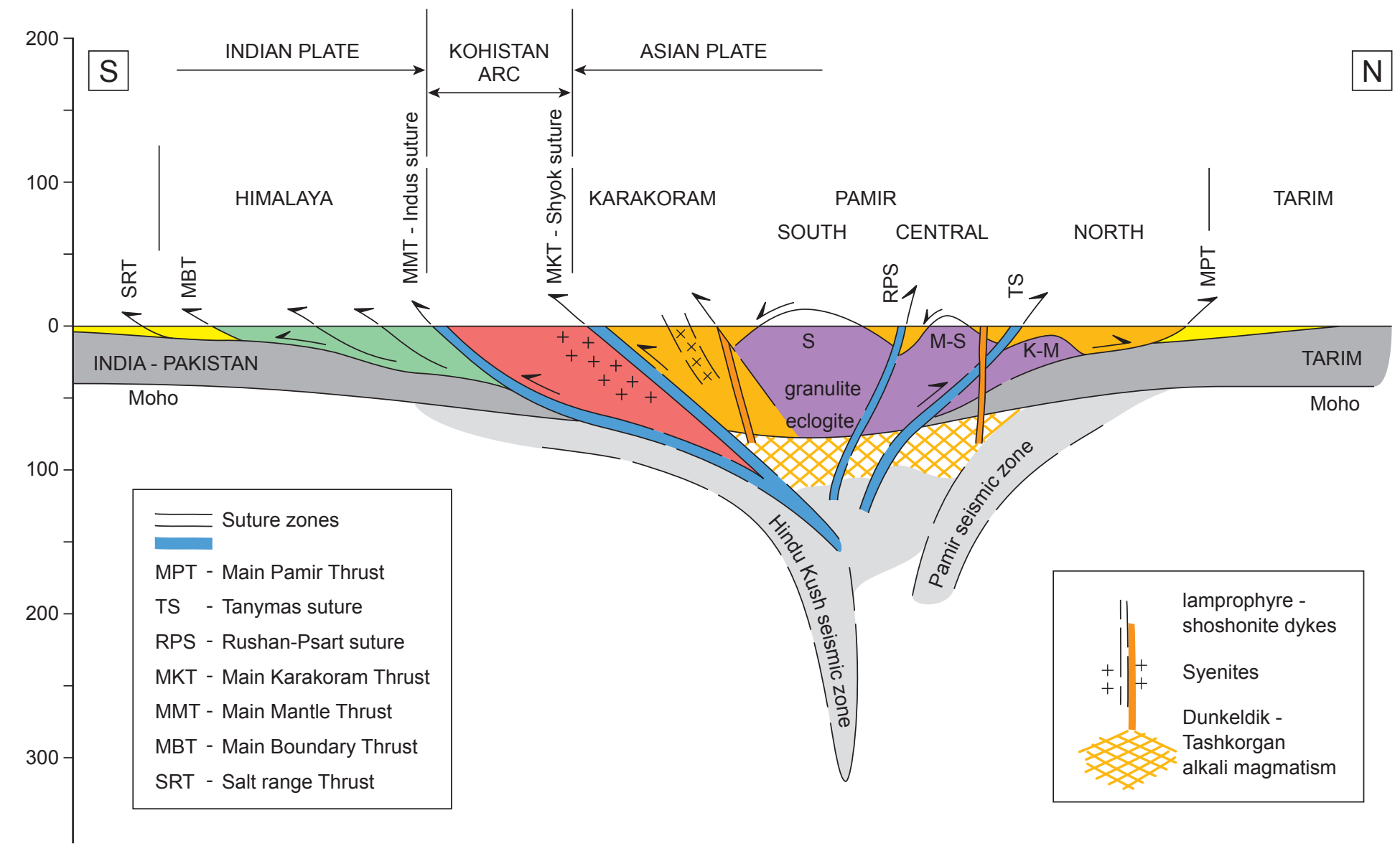


Click here to download figure Fig.16.pamir_karakoram-tibet timechart.pdf $\underline{\underline{\underline{*}}}$

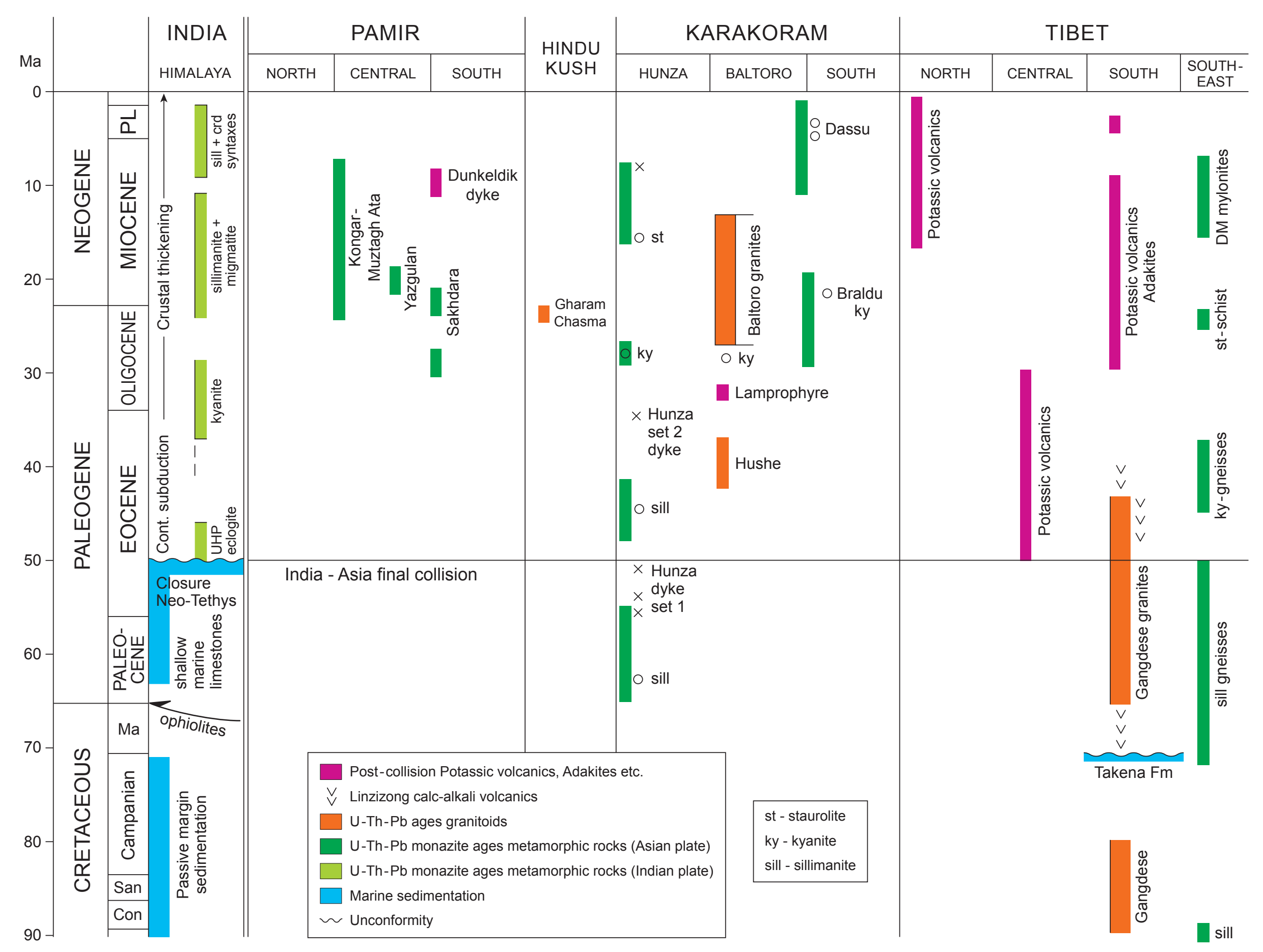

